\title{
Sustainable Synthesis and Precise Characterisation of Bio-based Star Polycaprolactone Synthesised with a Metal Catalyst and with Lipase
}

Payal Baheti, ${ }^{\mathrm{a}, \mathrm{b}}$ Olinda Gimello, ${ }^{\mathrm{a}}$ Cécile Bouilhac, ${ }^{\mathrm{a}^{*}}$ Patrick Lacroix-Desmazes, ${ }^{a}$ Steven M. Howdle ${ }^{\mathrm{b}^{*}}$

${ }^{a}$ ICGM, ENSCM, CNRS, Univ Montpellier, Montpellier, France

${ }^{\mathrm{b}}$ School of Chemistry, University of Nottingham, University Park, Nottingham NG7 2RD, United Kingdom

*Corresponding author e-mail: cecile.bouilhac@umontpellier.fr, steve.howdle@nottingham.ac.uk

Keywords: enzymatic polymerisation, star sorbitol poly( $\varepsilon$-caprolactone), Novozym 435

(Candida Antarctica lipase B), metal catalyst, bio-based, supercritical carbon dioxide 


\section{Abstract}

Bio-based building blocks and sustainable synthesis pathways were used to synthesise starshaped polymers composed of a $D$-sorbitol core and polycaprolactone arms by ring opening polymerisation (ROP). The use of volatile organic solvents was avoided and less energy intense reaction conditions were achieved by performing the ROP in the bulk or in a green solvent, supercritical $\mathrm{CO}_{2}\left(\mathrm{scCO}_{2}\right)$. Two catalysts were tested: conventional tin(II) 2ethylhexanoate $\left(\mathrm{Sn}(\mathrm{Oct})_{2}\right)$ which is a Food and Drug Administration (FDA) approved metal catalyst and an enzyme, Novozym 435 (Lipase B from Candida Antarctica immobilised on a solid support). The influence of the reaction medium and of the nature of the catalyst on the molecular weight, the dispersity and the architecture of the PCL stars was investigated. The star polymers were characterised by ${ }^{1} \mathrm{H}$ and ${ }^{31} \mathrm{P}$ nuclear magnetic resonance $\left({ }^{1} \mathrm{H}\right.$ and ${ }^{31} \mathrm{P}$ NMR) spectroscopy, size exclusion chromatography - multi-angle light scattering (SECMALS) and matrix-assisted laser desorption and ionisation-time of flight (MALDI-TOF) mass spectrometry. The use of $\mathrm{scCO}_{2}$ enabled the reduction of the reaction temperature of $\mathrm{Sn}(\mathrm{Oct})_{2}$ catalysed star $D$-sorbitol-polycaprolactone polymerisations from 140 to $95{ }^{\circ} \mathrm{C}$. In addition, star polymers were successfully synthesised by enzyme catalysis in the bulk or in $\mathrm{scCO}_{2}$ at $60{ }^{\circ} \mathrm{C}$; lower temperatures that could provide significant energy savings on a commercial scale. The catalyst was shown to have a pronounced influence on the architecture of the PCL stars. Regular star polymers were obtained in the presence of $\mathrm{Sn}(\mathrm{Oct})_{2}$ whereas Novozym 435 gave access to miktoarm-type star PCL. Finally, the influence of the number and length of the arms on the thermal properties of the star polymers was investigated by differential scanning calorimetry (DSC). 


\section{Introduction}

The accumulation of non-biodegradable plastics on earth has resulted in an increasing need for biodegradable polymers, ideally produced by green technologies. In addition, the simultaneously occurring depletion of fossil resources has promoted the utilisation of naturally occurring building blocks. ${ }^{1}$ At the same time, there has been a tremendous development in the synthesis of complex macromolecular architectures in order to design polymers tailored to specific functions and applications. In particular, star polymers have attracted attention, because of their unique rheological properties, lower hydrodynamic volume than their linear analogues, and their very interesting thermal, topological, and biological properties that are inaccessible from their linear counterparts. ${ }^{2,3,4,5}$ Star polymers have at least three arms of often similar lengths, fused on a central core and based on the nature and uniformity of their arms, they are classified into regular or miktoarm types. ${ }^{3,6}$ The special properties of such star-like structures result from the higher number of functional end groups and their highly branched nature, which causes, for example, a lower intrinsic viscosity, by reducing the amount of chain entanglements compared to linear polymers of similar molecular weight, and can lead to a reduced melting point. ${ }^{2,3,47,8}$ A prominent example of star polymers for commercial applications are Lubrizol's Asteric ${ }^{\mathrm{TM}}$ viscosity modifiers. In this case, star poly(alkyl methacrylates) with 9-13 arms are used as additives for lubricants to decrease viscosity at lower temperatures while at the same time ensuring a higher viscosity index, i.e. reducing the variation in viscosity with changing temperature. ${ }^{2}$ Star polymers can be synthesised by an arm first approach, in which arms are synthesised and then attached to the core, or by a core first approach. In the core first approach, the arms are polymerised from multifunctional initiators using, for example, ring opening polymerisation (ROP). Poly( $\varepsilon$-caprolactone) (PCL) is a particularly interesting polymer obtained by ROP 
since it is inexpensive, biocompatible and possesses a controlled degradability. In the future, the monomer $\varepsilon$-caprolactone $(\varepsilon-\mathrm{CL})$ could potentially be sourced from renewable resources. ${ }^{9,10,11}$ For instance, $\varepsilon$-CL could be obtained from lignocellulosic biomass derived 5hydroxymethylfurfural. $^{12,13}$ Additionally, $\varepsilon-\mathrm{CL}$ is an intermediate in the oxidation of cyclohexanol to adipic acid by an Acinetobacter sp. strain SE19 enzyme, resulting in a potential for biotechnological sourcing of $\varepsilon$-CL. ${ }^{14}$ Typically, star PCL are synthesised from polyhydroxy alcohols (such as glycerol, ${ }^{15,16}$ trimethylolpropane, ${ }^{17,18,19}$ pentaerythritol,,${ }^{15,16,18,19}$ di-trimethylolpropane, ${ }^{17} \mathrm{D}$-sorbitol, ${ }^{20}$ dipentaerythritol, ${ }^{17}$ and maltitol ${ }^{17}$ ) as initiators, which constitute the core of the stars. Multifunctional polymeric macroinitiators such as star poly(ethylene glycol) ${ }^{21}$ or hyperbranched polymers such as poly(2-hydroxyethyl methacrylate $)^{22}$ have also been employed to form star block copolymers with PCL. Sorbitol is of particular interest as a core for star PCL, since it is an inexpensive, highly valuable polyol commercially derived from renewable feedstocks such as corn-starch, cellulose, cassava, wheat, etc. ${ }^{23,24}$

Tin(II) 2-ethylhexanoate $\left(\mathrm{Sn}(\mathrm{Oct})_{2}\right)$ is commonly used as a catalyst ${ }^{20,25}$ for the ROP of $\varepsilon$-CL. Although $\mathrm{Sn}(\mathrm{Oct})_{2}$ is a well-known Food and Drug Administration (FDA) approved metal catalyst, there are increasing concerns regarding the presence of toxic metal catalysts in the final products. This is of particular importance for polymers in skin care or cosmetic products. In previous work, we have shown that extraction using supercritical $\mathrm{CO}_{2}\left(\mathrm{scCO}_{2}\right)$ can be used to reduce the amount of catalyst residue in polymer products. ${ }^{26}$ However, an alternative may be to avoid the use of a toxic metal catalyst and shift to more environmentally friendly alternatives such as enzymes. ${ }^{27,28}$ Lipase is the most important class of biocatalyst for ROP because of its abundance in nature, high specificity, regio- and enantioselectivity and low environmental impact. ${ }^{27}$ Uppenberg and co-workers discovered in 1994 that this selectivity was due to the 'open' conformation of the catalytic triad Ser-His-Asp in the active 
site of CaLB, which restricts the accessibility of the active site for certain substrates. ${ }^{29}$ In particular, Novozym 435 (Lipase B from Candida Antarctica (CaLB) immobilised on a macroporous acrylic resin) has shown extraordinary reactivity towards a wide range of cyclic monomers, high catalytic activity, good solvent resistance and has been broadly studied as a biocatalyst for polyester synthesis. ${ }^{28}$

Enzymatic ROP (eROP) of $\varepsilon$-CL by Novozym 435 has been studied extensively in the bulk and in various organic solvents to give linear PCL. ${ }^{30,31}$ However, an obstacle in enzyme catalysis is the instability of the catalysts. At temperatures higher than $100{ }^{\circ} \mathrm{C}$, which is typically employed in ROP of $\varepsilon$-CL in the bulk, denaturation of the protein structure occurs. ${ }^{32}$ The optimum temperature for CaLB catalysis for enzymatic polyesters synthesis is thus between 60 and $70{ }^{\circ} \mathrm{C} .{ }^{33,34}$ Another challenge is the sensitivity of enzymes towards certain solvents, such as polar solvents, which interfere with the hydrogen bonding in the protein structure, thereby affecting the catalytic activity of the enzyme. ${ }^{35}$ For example, Novozym 435 displays relatively high selectivity towards primary alcohols compared to secondary alcohols. However, the presence of polar solvent affects the selectivity of Novozym 435. For instance, Xue et al. achieved three-arm star PCL polymers using glycerol as the initiator in presence of 1,4-dioxane at $70{ }^{\circ} \mathrm{C}$ confirming initiation from a secondary hydroxy group. ${ }^{36}$ Other factors such as catalyst loading and the immobilisation process on the support can also influence the catalytic activity and regioselectivity. ${ }^{37,38,39}$ Regarding the enantioselectivity of Novozym 435, Gross and co-workers have investigated the incorporation of alditols, such as $D$-sorbitol, $D$-galactitol, and $D$-mannitol into copolyesters with adipic acid and 1,8-octanediol by polycondensation and observed the highest molecular weights as well as the highest degree of branching for the polyesters with $D$-mannitol as the copolymer, indicating a preference of Novozym 435 towards all R-configuration of this alditol. Accordingly, incorporation of $D$ - 
sorbitol (SRRR) gave higher molecular weights and a higher degree of branching than the incorporation of $D$-galacitol. ${ }^{40}$

A potential alternative to the volatile organic solvents or reactions in the bulk at high temperatures is the use of non-toxic supercritical $\mathrm{CO}_{2}\left(\mathrm{scCO}_{2}\right) .{ }^{41}$ The gas-like diffusivity of $\mathrm{scCO}_{2}$ into polymer matrices provides a unique opportunity to liquefy polymers at temperatures below their glass transition temperature $\left(T_{\mathrm{g}}\right)$ and melting point $\left(T_{\mathrm{m}}\right)$. This not only lowers the viscosity of the reaction medium dramatically but also allows for a more sustainable low-temperature processing of polymers; both factors lead to significant process energy savings. ${ }^{42,43} \mathrm{ScCO}_{2}$ is a well-established and versatile solvent for polymerisation, ${ }^{44}$ polymer modification, ${ }^{46,47}$ polymer blending, ${ }^{43}$ purification, ${ }^{43}$ and extraction, ${ }^{43}$ and has been successfully employed as a foaming agent, ${ }^{48}$ and for polymer particle formation. ${ }^{43,49}$ The liquefying ability of $\mathrm{scCO}_{2}$ has previously been exploited for the synthesis of a range of polymeric materials with controlled molecular weights and narrow dispersities using enzyme catalyst at near ambient temperature, which ensures the stability of the biocatalysts. ${ }^{50,51,45,52}$ For example, $\mathrm{scCO}_{2}$ was previously employed as a solvent for the synthesis of linear PCL by ROP of $\varepsilon$-CL using $\mathrm{Sn}(\mathrm{Oct})_{2}$ or Novozym 435 as a catalyst. ${ }^{33,50,53,54}$

In this work, we studied several polyols, including 1,6-hexanediol, glycerol, pentaerythritol and triglycerol, as initiators for the synthesis of star polyol-PCL by ring opening polymerisation. Eventually, we investigated the synthesis of complex star PCL architectures using a renewable polyol core, $D$-sorbitol, as the initiator, aiming at establishing an environmentally benign process to make biodegradable star $D$-sorbitol-PCL under mild conditions. A mild synthetic procedure is of particular importance when using temperature sensitive polyols such as $D$-sorbitol as the initiator since it is well known to dehydrate into isosorbide at elevated temperatures. ${ }^{55}$ Thus, we first investigated the use of $\mathrm{scCO}_{2}$ as a solvent for the $\mathrm{Sn}(\mathrm{Oct})_{2}$ catalysed star PCL synthesis at low temperatures $\left(95^{\circ} \mathrm{C}\right)$, taking 
advantage of the plasticisation effects of $\mathrm{scCO}_{2}$. The results were compared to the synthesis in the bulk at $140{ }^{\circ} \mathrm{C}$. Moreover, we reported on the synthesis of star PCL with a $D$-sorbitol core using Novozym 435 as the catalyst for the ROP in $\mathrm{scCO}_{2}$ and in the bulk. Finally, we compared the architecture of the PCL stars synthesised with both catalysts. We also investigated the effect of the number and the variable length of the arms of the star PCL on the thermal properties of the polymers.

\section{Experimental}

\subsection{Materials}

$\varepsilon$-Caprolactone ( $\varepsilon$-CL, 97\%), D-sorbitol (>98\%), pentaerythritol (97\%), glycerol (99\%), 1,6hexanediol (97\%), triglycerol (60\%), tin (II) 2-ethylhexanoate ( $\left.\mathrm{Sn}(\mathrm{Oct})_{2}, 98 \%\right)$ and 2-chloro4,4,5,5-tetramethyl-1,3,2-dioxaphospholane (95\%) (Cl-TMDP) were purchased from Sigma Aldrich (UK). $\varepsilon$-CL was dried over $\mathrm{CaH}_{2}$ for $48 \mathrm{~h}$ followed by vacuum distillation and stored under an inert atmosphere. 1,6-Hexanediol, glycerol, pentaerythritol, $D$-sorbitol and $\operatorname{Sn}(\mathrm{Oct})_{2}$ were stored in a desiccator and dried under vacuum at $25^{\circ} \mathrm{C}$ overnight before use. Novozym 435 (10 wt\% of Candida antarctica (CaLB) immobilised on cross-linked acrylic resin; enzyme activity is 5000 units/mg of protein) was kindly donated by Novozymes (Denmark), stored at $4{ }^{\circ} \mathrm{C}$, dried overnight under vacuum $\left(25^{\circ} \mathrm{C}\right)$ and degassed for $30 \mathrm{~min}$ before use. All the solvents were of analytical grade or HPLC-grade and used as received. Supercritical Fluid Chromatography (SFC) grade carbon dioxide (minimum purity $99.9 \%$ ) was purchased from BOC gases (UK) and used as received. 


\subsection{Solvent-free synthesis of star polycaprolactone from $D$-sorbitol using $\operatorname{Sn}(\operatorname{Oct})_{2}$ as the catalyst}

The glassware was flamed dried before use. $\varepsilon$-Caprolactone (5.15 g, $45.12 \mathrm{mmol}), D$-sorbitol $(156 \mathrm{mg}, 0.86 \mathrm{mmol})$ and $10 \mathrm{~mol} \%$ of $\mathrm{Sn}(\mathrm{Oct})_{2}(34 \mathrm{mg}, 0.09 \mathrm{mmol})$ with respect to $D$ sorbitol were added to a $25 \mathrm{~mL}$ round-bottom flask equipped with a magnetic stirrer at $300 \mathrm{rpm}$. The reagents were degassed with argon for $30 \mathrm{~min}$ and subsequently heated to $95{ }^{\circ} \mathrm{C}$ for 7 days or to $140{ }^{\circ} \mathrm{C}$ for $10 \mathrm{~h}$, respectively. The conversion was monitored by ${ }^{1} \mathrm{H}$ NMR by taking aliquots until $95-99 \%$ monomer conversion was reached. The resulting polymer was dissolved in THF, precipitated in cold ethanol and dried under vacuum (gravimetric yield: 96-97\%).

SEC-MALS $(\mathrm{THF}): M_{\mathrm{n}}^{\text {SEC-MALS }}=5600 \mathrm{~g} \mathrm{~mol}^{-1}, Ð=1.03$

\subsection{Solvent-free synthesis of star polycaprolactone from $D$-sorbitol using Novozym 435 as the catalyst}

The glassware was flame dried before use. $\varepsilon$-CL $(5.15 \mathrm{~g}, 45.12 \mathrm{mmol})$ was added into a three neck round bottom flask equipped with a mechanical stirrer, under inert conditions and heated in an oil-bath at $110{ }^{\circ} \mathrm{C}$. $D$-Sorbitol $(156 \mathrm{mg}, 0.858 \mathrm{mmol})$ was then introduced under mechanical agitation at $300 \mathrm{rpm}$. Although the reaction mixture was initially biphasic, a homogeneous melt of $D$-sorbitol and $\varepsilon$-CL was observed within $30 \mathrm{~min}$. Subsequently, the temperature was reduced to $60{ }^{\circ} \mathrm{C}$ and Novozym 435 beads $(154 \mathrm{mg}, 3 \mathrm{wt} \%$ or $515 \mathrm{mg}$, $10 \mathrm{wt} \%$ with respect to $\varepsilon$-CL) were introduced. The reaction was continued for $13 \mathrm{~h} \mathrm{(3 \textrm {wt } \%}$ Novozym 435, 85-87\% conversion) or for 7 h (10 wt $\%$ Novozym 435, 89-91\% conversion). After polymerisation, the reaction mixture was dissolved in THF and the enzyme beads were separated by filtration. Subsequently, the excess of solvent was evaporated, and the crude polymer was purified by precipitation into cold ethanol from THF and dried under vacuum. 
For both reactions using either $3 \mathrm{wt} \%$ or $10 \mathrm{wt} \%$ Novozym 435 , the gravimetric yield after recycling enzyme was $62-65 \%$.

SEC-MALS (THF): $M_{\mathrm{n}}^{\text {SEC-MALS }}(3 \mathrm{wt} \%$ Novozym 435$)=5650 \mathrm{~g} \mathrm{~mol}^{-1}, Ð=1.34$

SEC-MALS (THF): $M_{\mathrm{n}}^{\text {SEC-MALS }}\left(10 \mathrm{wt} \%\right.$ Novozym 435) $=7800 \mathrm{~g} \mathrm{~mol}^{-1}, Ð=1.36$

2.4. Synthesis of star polycaprolactone from $D$-sorbitol using $\operatorname{Sn}(\mathrm{Oct})_{2}$ as the catalyst in supercritical $\mathrm{CO}_{2}$

The stainless steel high-pressure autoclave reactor $(20 \mathrm{~mL})$ used for the synthesis in $\mathrm{scCO}_{2}$ has been described previously. ${ }^{51}$

Star $D$-sorbitol-PCL was synthesised in $\mathrm{scCO}_{2}$ using $\mathrm{Sn}(\mathrm{Oct})_{2}$ as catalyst following the same procedure as given above for the synthesis in the bulk but at $95{ }^{\circ} \mathrm{C} . D$-sorbitol $(93.8 \mathrm{mg}$, $0.52 \mathrm{mmol})$ and $10 \mathrm{~mol} \%$ of $\mathrm{Sn}(\mathrm{Oct})_{2}$ relative to $D$-sorbitol $(20.8 \mathrm{mg}, 0.05 \mathrm{mmol})$ were loaded into the base of the autoclave and degassed with $\mathrm{CO}_{2}$ at 3 bar to ensure removal of air. E-CL (3 ml, $27.07 \mathrm{mmol})$ was then added. The reactor was pressurised to $70 \mathrm{bar}$ and gradually heated to $95{ }^{\circ} \mathrm{C}\left(10{ }^{\circ} \mathrm{C} / \mathrm{min}\right)$. Subsequently, the pressure was increased to 240 bar by the addition of $\mathrm{CO}_{2}$ and the reaction was allowed to stabilise at $95{ }^{\circ} \mathrm{C}$ and 240 bar for 10 min. Only after the desired reaction condition $\left(95{ }^{\circ} \mathrm{C}\right.$ and 240 bar) was attained, the reaction mixture was agitated using a mechanical stirrer at $300 \mathrm{rpm}$ for 2.5 days. The gravimetric yield after polymerisation was $95-96 \%$ (polymer precipitated in cold ethanol from THF solution and dried under vacuum).

SEC-MALS $(\mathrm{THF}): M_{\mathrm{n}}^{\text {SEC-MALS }}=6100 \mathrm{~g} \mathrm{~mol}^{-1}, Ð=1.11$

\subsection{Synthesis of star polycaprolactone from $D$-sorbitol using Novozym 435 as the} catalyst in supercritical $\mathrm{CO}_{2}$

Before the reaction, the autoclave was dried by heating to $95{ }^{\circ} \mathrm{C}$ for $1 \mathrm{~h}$, to avoid any contamination by water. $D$-sorbitol $(156.3 \mathrm{mg}, 0.858 \mathrm{mmol}$ ), and Novozym 435 (3 wt\% or 10 
$\mathrm{wt} \%$ relative to monomer) were transferred to the base of the autoclave and degassed with $\mathrm{CO}_{2}$ for $15 \mathrm{~min}$ at 3 bar pressure. $\varepsilon$-CL $(5.15 \mathrm{~g}, 45.1 \mathrm{mmol})$ was then injected into the autoclave. The autoclave was pressurised with $\mathrm{CO}_{2}$ to 70 bar and heated to $40{ }^{\circ} \mathrm{C}$. The $\mathrm{CO}_{2}$ was added to the autoclave up to 50 bar and the temperature was set to $60{ }^{\circ} \mathrm{C}$. Subsequently, the pressure was raised up to 217 bar. After obtaining the desired reaction conditions $\left(60{ }^{\circ} \mathrm{C}\right.$,

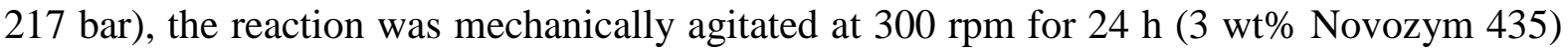
or for $7 \mathrm{~h}(10 \mathrm{wt} \%$ Novozym 435$)$ to reach $96-99 \%$ monomer conversion. The reaction was stopped by cooling to ambient temperature, turning off the stirring, and venting the autoclave (at $\mathrm{T}<20{ }^{\circ} \mathrm{C}, \mathrm{P}=55-82 \mathrm{bar}$ ). The crude polymer was dissolved in THF and the enzyme beads were separated from the polymer by filtration. The polymer was then precipitated in cold ethanol from THF and dried under vacuum. The gravimetric yield after recycling enzyme was $75-79 \%$, regardless of the catalyst loading.

SEC-MALS (THF): $M_{\mathrm{n}}^{\text {SEC-MALS }}(3 \mathrm{wt} \%$ Novozym 435$)=8800 \mathrm{~g} \mathrm{~mol}^{-1}, Ð=1.24$

SEC-MALS (THF): $M_{\mathrm{n}}^{\text {SEC-MALS }}\left(10 \mathrm{wt} \%\right.$ Novozym 435) $=10100 \mathrm{~g} \mathrm{~mol}^{-1}, Ð=1.23$ 


\section{Results and discussion}

Ring-opening polymerisation (ROP) of $\varepsilon$-caprolactone ( $\varepsilon$-CL) was carried out in the presence of $D$-sorbitol as the initiator and using two different catalytic systems (Scheme 1): a metalbased catalyst $\left(\mathrm{Sn}(\mathrm{Oct})_{2}\right)$ and an enzymatic catalyst (Novozym 435). The influence of both catalysts on the architecture of star $D$-sorbitol-PCL synthesised in the bulk or in $\mathrm{scCO}_{2}$ was investigated, thereby avoiding organic solvents as the reaction medium.
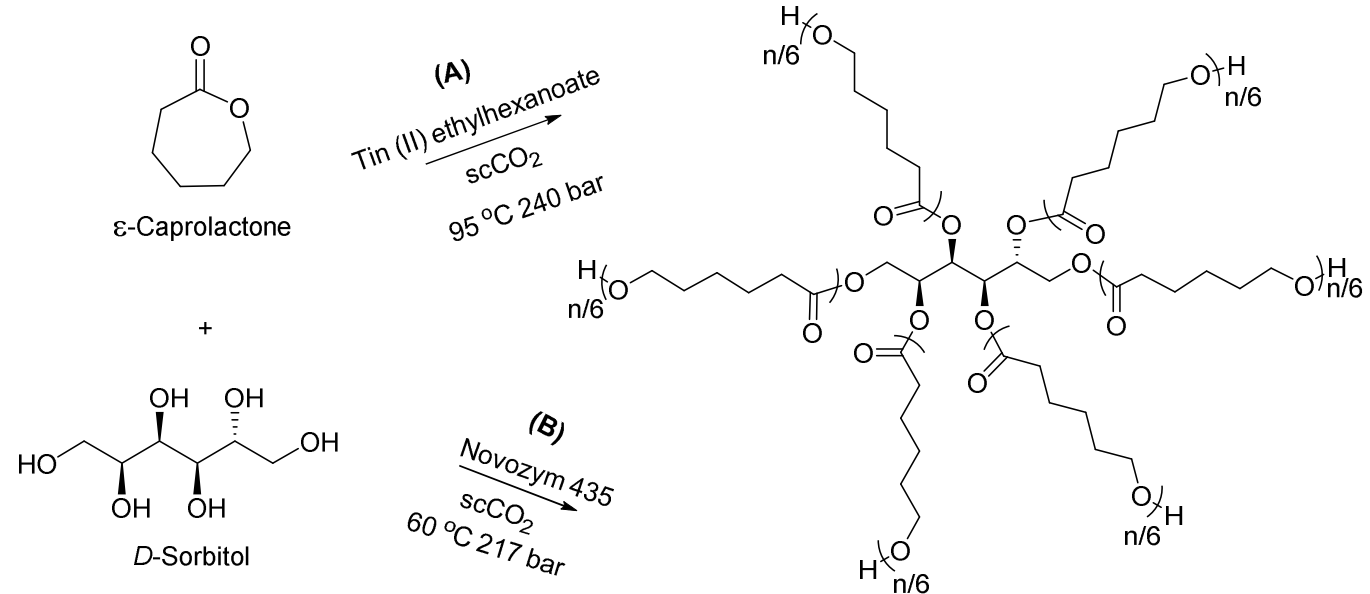

$\mathrm{n}=$ total $\varepsilon-\mathrm{CL}$ units

Scheme 1. ROP of $\varepsilon$-caprolactone from $D$-sorbitol to afford a star $D$-sorbitol-PCL using (A) a conventional metal catalyst $\left(\mathrm{Sn}(\mathrm{Oct})_{2}\right)$; and (B) an enzyme (Novozym 435) in the bulk or using $\mathrm{scCO}_{2}$.

\subsection{Synthesis of star $D$-sorbitol-PCL via $\operatorname{Sn}(\mathbf{O c t})_{2}$ catalysed $\mathrm{ROP}$ in the bulk and in $\mathrm{ScCO}_{2}$}

Before investigating the star PCL polymers initiated by $D$-sorbitol, less complex polymer architectures were synthesised from simpler alcohols such as 1,6-hexanediol, glycerol, pentaerythritol and triglycerol in the bulk (Scheme S1). These syntheses provided the first overview of suitable polymerisation conditions and insights on how the structure of alcohol 
in combination with $\mathrm{Sn}(\mathrm{Oct})_{2}$ as a catalyst and the temperature might influence the rate of polymerisation (ESI Table S1).

First linear 1,6-hexanediol was used as an initiator for the synthesis of PCL with a targeted molecular weight of $1000 \mathrm{~g} \mathrm{~mol}^{-1}$ at $95{ }^{\circ} \mathrm{C}$. Full conversion was observed within $1 \mathrm{~h}$ (Table S1, Entry 1). However, when the amount of initiator was lowered to target a higher molecular weight of $6000 \mathrm{~g} \mathrm{~mol}^{-1}$ the monomer consumption slowed down after $84 \%$ conversion, after $6.5 \mathrm{~h}$ (Table S1, Entry 2). At first, this phenomenon was attributed to lower mass transfer due to lower mobility of chains at higher viscosity. As the temperature was increased to $140{ }^{\circ} \mathrm{C}$ higher monomer conversions of $97-99 \%$ were observed regardless of the initiator (Table S1, Entry $2 v s$. Entries 3-7). Nevertheless, the polymerisation rate successively slowed down as the number of hydroxy groups on the initiator increased and the reaction time required to reach $>98 \%$ conversion increased (Table S1, Entries 3-7). This indicates that, despite the high temperature, for polymerisation at $140{ }^{\circ} \mathrm{C}$, the choice of initiator also influences the kinetics of $\mathrm{Sn}(\mathrm{Oct})_{2}$ as a catalyst. To investigate how the temperature and the amount of catalyst affect the polymerisation of $\varepsilon$-CL when using $D$-sorbitol, polymerisations in the bulk were conducted at two temperatures of 95 and $140{ }^{\circ} \mathrm{C}$.

For star $D$-sorbitol-PCL polymerisation with $\mathrm{Sn}(\mathrm{Oct})_{2}$ at 95 and $140{ }^{\circ} \mathrm{C}$ the evolution of $\ln \left([\mathrm{M}]_{0} /[\mathrm{M}]_{\mathrm{t}}\right)$ with time is linear (Figure 1 ), indicating that rate of polymerisation is first order with respect to the monomer. When conducting the polymerisations at $95{ }^{\circ} \mathrm{C}$ in the bulk, an induction period of approximately $65-70 \mathrm{~h}$ is observed, but this is common at lower temperatures. For example, Storey et al. observed an induction period of $40 \mathrm{~h}$ at $80{ }^{\circ} \mathrm{C}$ in the ROP of $\varepsilon$-CL using ethylene glycol as the initiator. ${ }^{56}$ Slow heat transfer and the choice of initiator are factors that contribute to induction periods for $\mathrm{Sn}(\mathrm{Oct})_{2}$ catalysed ROP of $\varepsilon$-CL. ${ }^{57}$ By contrast, as the temperature is increased to $140{ }^{\circ} \mathrm{C}$ the rate of monomer consumption increases dramatically and $\ln \left([\mathrm{M}]_{0} /[\mathrm{M}]_{\mathrm{t}}\right.$ ) increases linearly with time (Figure 1). A short 
induction period of up to $1-1.5 \mathrm{~h}$ was also observed at $140{ }^{\circ} \mathrm{C}$, which can be attributed to the coordination-insertion of the $\mathrm{Sn}(\mathrm{Oct})_{2}-D$-sorbitol complex with $\varepsilon$-CL.

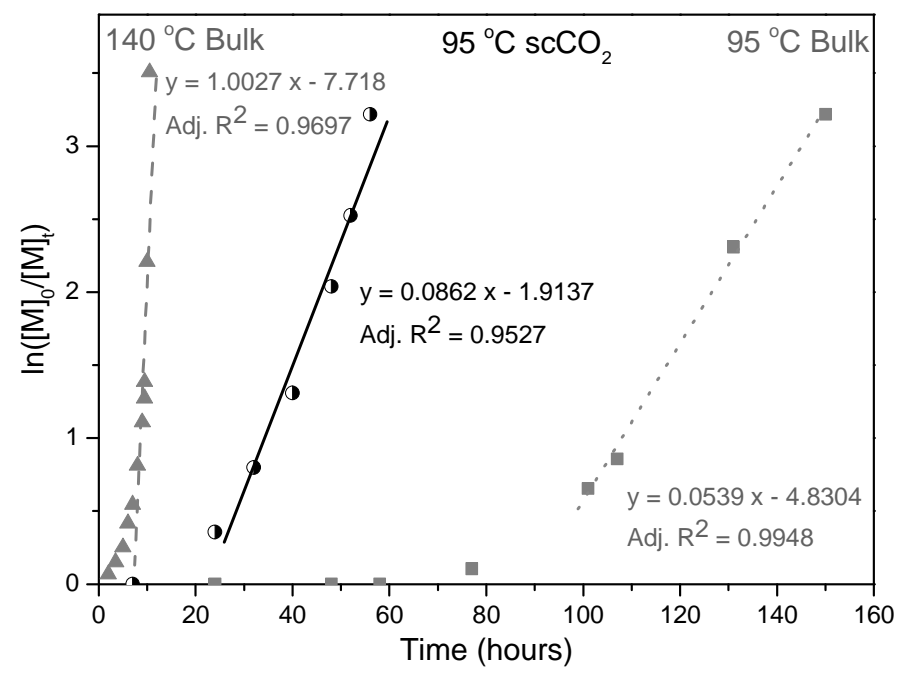

Figure 1. A plot of $\ln \left([\mathrm{M}]_{0} /[\mathrm{M}]_{\mathrm{t}}\right) v s$. polymerisation time for the synthesis of star $D$-sorbitolPCL in the bulk at 95 and $140{ }^{\circ} \mathrm{C}$ and in $\mathrm{scCO}_{2}$ at $95^{\circ} \mathrm{C}$.

A monomer conversion of $97-98 \%$ was achieved within $10.5 \mathrm{~h}$ at $140{ }^{\circ} \mathrm{C}$ whereas the same conversion was only obtained after $150 \mathrm{~h}$ at $95{ }^{\circ} \mathrm{C}$ (Table 1, Entry $1 v s$. Entry 3) (Figure 1). Furthermore, at a lower temperature $\left(95{ }^{\circ} \mathrm{C}\right)$ a progressively faster rate of monomer consumption was witnessed as the concentration of $\mathrm{Sn}(\mathrm{Oct})_{2}$ catalyst was raised 5 fold from $10 \mathrm{~mol} \%$ (Table 1, Entry 1) to $50 \mathrm{~mol} \%$ (Table 1, Entry 2). Although $\mathrm{Sn}(\mathrm{Oct})_{2}$ is FDA approved, it is clear that producing polyesters uncontaminated with possible toxic metallic residues would be desirable for biomedical applications. ${ }^{58,54}$ In addition, it is also difficult to completely remove the metal catalyst from the product even after several precipitations. Thus, increasing the catalyst content is highly undesirable.

The use of $\mathrm{scCO}_{2}\left(95^{\circ} \mathrm{C}, 240\right.$ bar $)$ considerably reduced the induction period of the ROP compared to the bulk polymerisation from $70 \mathrm{~h}$ to less than $15 \mathrm{~h}$ (Figure 1). This induction period was followed by a linear trend for the evolution of $\ln \left([\mathrm{M}]_{0} /[\mathrm{M}]_{\mathrm{t}}\right)$ during the 
propagation stage. Additionally, the use of $\mathrm{scCO}_{2}$ also enhanced the propagation rate in comparison to the bulk reaction (Table 1, Entry 1 and Entry 2 vs. Entry 4) (Figure 1).

Table 1. Synthesis of star $D$-sorbitol-PCL by ROP in the bulk and in $\mathrm{scCO}_{2}$ in the presence of $\mathrm{Sn}(\mathrm{Oct})_{2}$.

\begin{tabular}{|c|c|c|c|c|c|c|c|c|c|c|c|}
\hline \multirow[b]{2}{*}{ Entry } & \multirow[b]{2}{*}{ Solv. } & \multirow[b]{2}{*}[\mathrm{C}]{$^{\mathrm{a}}$} & \multirow{2}{*}{$\begin{array}{c}\mathrm{T} \\
\left({ }^{\circ} \mathrm{C}\right)\end{array}$} & \multirow{2}{*}{$\begin{array}{l}\mathrm{t} \\
(\mathrm{h})\end{array}$} & \multicolumn{3}{|c|}{${ }^{1} \mathrm{H}$ NMR } & \multicolumn{2}{|c|}{ SEC-MALS } & $\begin{array}{c}\text { SEC- } \\
\text { MALS/ } \\
{ }^{1} \mathrm{H} \text { NMR } \\
\end{array}$ & \multirow{2}{*}{$\begin{array}{c}\text { SEC } \\
\begin{array}{c}\text { Slope } \\
(\alpha)\end{array}\end{array}$} \\
\hline & & & & & $\begin{array}{c}\text { Conv. }{ }^{b} \\
(\%)\end{array}$ & $\begin{array}{l}D P_{\mathrm{n}} \\
\text { NMR b } \\
(\operatorname{arm})\end{array}$ & $\begin{array}{l}M_{\mathrm{n}}^{\mathrm{H}-\mathrm{NMR} \mathrm{b}} \\
\quad(\mathrm{arm}) \\
\left(\mathrm{g} \mathrm{mol}^{-1}\right)\end{array}$ & $\begin{array}{c}M_{\mathrm{n}}{ }^{\text {SEC-MALS }} \\
(\text { star polymer })^{\mathrm{c}} \\
\quad\left(\mathrm{g} \mathrm{mol}^{-1}\right)\end{array}$ & $\bigoplus^{\mathrm{c}}$ & $\begin{array}{l}N_{\text {arms }}^{\text {SEC- }} \\
\text { MALS/NMR d }\end{array}$ & \\
\hline Entry 1 & & 0.1 & 95 & 150 & 97 & 11.3 & 1290 & 5900 & 1.12 & 4.5 & 0.35 \\
\hline Entry 2 & Bulk & 0.5 & 95 & 20 & 99 & 11.0 & 1250 & 5500 & 1.38 & 4.4 & 0.35 \\
\hline Entry 3 & & 0.1 & 140 & 10.5 & 97 & 9.7 & 1100 & 5600 & 1.03 & 5.1 & 0.27 \\
\hline Entry 4 & $\mathrm{scCO}_{2}$ & 0.1 & 95 & 56 & 96 & 11.0 & 1250 & 6100 & 1.11 & 4.9 & 0.39 \\
\hline
\end{tabular}

M: Monomer $(\varepsilon-C L)$, I: Initiator (D-sorbitol) and C: Catalyst $\left(\operatorname{Sn}(\mathrm{Oct})_{2}\right) .{ }^{\mathrm{a}}[\mathrm{M}]:[\mathrm{I}]:[\mathrm{C}]=52.6: 1:[\mathrm{C}]$ based on $M_{\mathrm{n}}^{\text {targ }}=[\mathrm{M}]:[\mathrm{I}] \times M_{\varepsilon-\mathrm{CL}}$ at $100 \%$ monomer conversion $=6000 \mathrm{~g} \mathrm{~mol}^{-1} ;{ }^{\mathrm{b}}$ Determined by ${ }^{1} \mathrm{H}$ NMR. ${ }^{\mathrm{c}}$ Degree of polymerisation and average molecular weight of arms following Eq. S1 and S2, respectively. ${ }^{\mathrm{c}}$ Molecular weight and dispersity $(\nexists)$ determined by SEC-MALS. ${ }^{\mathrm{d}}$ Average number of arms estimated by SEC-MALS and ${ }^{1} \mathrm{H}$ NMR following Eq. S4 ${ }^{\mathrm{e}}$ Mark-Houwink slope $(\alpha)$ determined by SEC following Eq. S5.

The monomer $\varepsilon$-CL is solubilised by $\operatorname{scCO}_{2}\left(95{ }^{\circ} \mathrm{C}, 240\right.$ bar) and the resulting mixture plasticises $D$-sorbitol. ${ }^{26}$ Thus, the coordination-complexation between the tin catalyst and alkoxides of $D$-sorbitol and $\varepsilon$-CL can take place faster in $\mathrm{scCO}_{2}$ than in the bulk thereby reducing the induction period (Figure 1). The reduction of the induction period and the higher rate of propagation in $\mathrm{scCO}_{2}$ as compared to the bulk at $95^{\circ} \mathrm{C}$ can be attributed to the unique 'gas-like' mass transfer properties of $\mathrm{scCO}_{2}{ }^{59}$

Regardless of the reaction temperature or induction periods, the molecular weight of the star $D$-sorbitol-PCL increased linearly with monomer conversion both in the bulk and in $\mathrm{scCO}_{2}$, indicating a well-controlled polymerisation (Figure $\mathrm{S} 1-\mathrm{S} 2$ ). The resulting star $D$-sorbitolPCL polymers were analysed by SEC-MALS (Figure 2) using the $\mathrm{dn} / \mathrm{dc}$ value of $0.072 \mathrm{~mL} \mathrm{~g}^{-}$ ${ }^{140}$ The experimental molecular weights $\left(M_{\mathrm{n}}^{\text {SEC-MALS }}(\right.$ star polymer $\left.)=5500-6100 \mathrm{~g} \mathrm{~mol}^{-1}\right)$ of star $D$-sorbitol-PCL synthesised using $\mathrm{Sn}(\mathrm{Oct})_{2}$ as the catalyst were in good agreement 
with the targeted $\left(M_{\mathrm{n}}{ }^{\operatorname{targ}}=6000 \mathrm{~g} \mathrm{~mol}^{-1}\right.$, Table 1$)$. In addition, polymers with narrow dispersities $\left(\bigoplus=1.03\right.$ - 1.12) were obtained in both the bulk and $\mathrm{scCO}_{2}$ (Table 1 , Entry 1 , Entry 3 and Entry 4) which is in good agreement with data on ROP of PCL from the literature. ${ }^{57,58}$ An increase of dispersity $(\bigoplus=1.38$ vs. 1.12) was observed for higher catalyst loading at $95{ }^{\circ} \mathrm{C}$ in the bulk (Table 1 , Entry 2 vs. Entry 1 ) and this could be attributed to the inter- and intramolecular transesterification reactions, that predominate when a higher amount of $\mathrm{Sn}(\mathrm{Oct})_{2}$ catalyst is present in the reaction mixture.

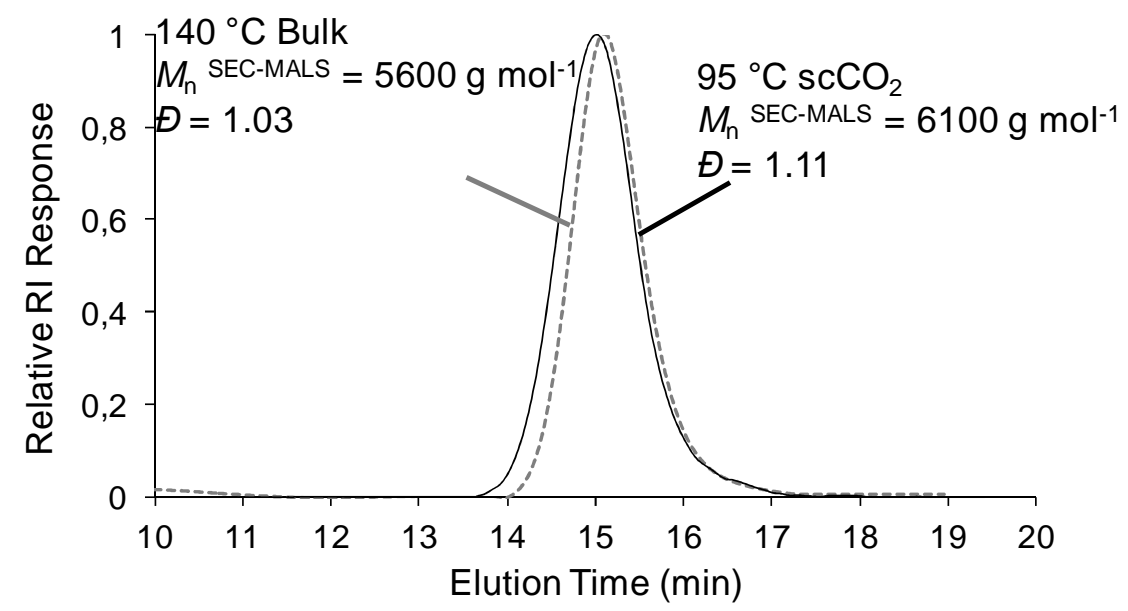

Figure 2. SEC-MALS traces overlay of star $D$-sorbitol-PCL catalysed by $\mathrm{Sn}(\mathrm{Oct})_{2}$ in the bulk $\left(140{ }^{\circ} \mathrm{C}\right)$ and in $\mathrm{scCO}_{2}\left(95^{\circ} \mathrm{C}, 240\right.$ bar) (Table 1 , Entry 3 vs. 4$)$.

These data show that significantly lower temperatures can be utilised using $\mathrm{scCO}_{2}$, although this does increase the reaction time. Most importantly, this opens up the opportunity to use temperature sensitive catalyst such as enzymes, which can catalyse ROP at lower temperatures than $\mathrm{Sn}(\mathrm{Oct})_{2} .^{60}$ 


\subsection{Synthesis of star $D$-sorbitol-PCL via Novozym 435 catalysed ROP in the bulk and in $\mathrm{scCO}_{2}$}

Lipases exhibit higher catalytic activity at lower temperatures. ${ }^{61}$ Hence, enzymatic ringopening polymerisations (eROP) of $\varepsilon$-CL initiated by $D$-sorbitol were conducted at $60{ }^{\circ} \mathrm{C}$ with varying enzyme concentrations ( $3 \mathrm{wt} \%$ and $10 \mathrm{wt} \%$ relative to monomer, Table 2$)$ to investigate the influence of the enzyme loading on the kinetics of the polymerisation, molecular weight and architecture of the polymers. Since Novozym 435 contains $10 \mathrm{wt} \%$ of CaLB attached to a polymeric support, the actual weight ratio of CaLB to $\varepsilon$-CL used for this study was 0.3 and $1 \mathrm{wt} \%$ for 3 and $10 \mathrm{wt} \%$ Novozym 435, respectively. The analytical results of the eROP polymerisation of PCL (Table 2) and the kinetics of the eROP for $M_{\mathrm{n}}{ }^{\operatorname{targ}}=6000$ $\mathrm{g} \mathrm{mol}^{-1}$ in the bulk and in $\mathrm{scCO}_{2}$ are summarised (Figure S3-S6). For the polymerisation in $\mathrm{scCO}_{2}$, all the reactants were introduced in the reaction vessel before adding $\mathrm{CO}_{2}$. By contrast, for polymerisations in the bulk, it was first necessary to intimately mix the $D$ sorbitol $\left(T_{\mathrm{m}}=98-99^{\circ} \mathrm{C}\right)$ with $\varepsilon$-CL at $110{ }^{\circ} \mathrm{C}$ before introducing the Novozym 435 at a lower temperature of $60{ }^{\circ} \mathrm{C}$.

Interestingly, the eROP in the bulk at a Novozym 435 loading of $10 \mathrm{wt} \%$ at $60{ }^{\circ} \mathrm{C}$ reached $91 \%$ conversion within $7 \mathrm{~h}$ (Table 2, Entry 4) whereas the ROP in the bulk catalysed by $\mathrm{Sn}(\mathrm{Oct})_{2}$ reached only a slightly higher conversion of $97 \%$ within $10.5 \mathrm{~h}$ at a significantly higher temperature of $140{ }^{\circ} \mathrm{C}$ (Table 1, Entry 3). This effect is even more pronounced in $\mathrm{scCO}_{2}$, where comparable results to the polymerisation in the bulk are obtained for enzyme catalysis, i.e. a conversion of $96 \%$ after just $7 \mathrm{~h}$ at $60{ }^{\circ} \mathrm{C}$ (Table 2, Entry 4), whereas much longer reaction times $(56 \mathrm{~h})$ and higher temperatures $\left(95^{\circ} \mathrm{C}\right)$ are required with $\mathrm{Sn}(\mathrm{Oct})_{2}$ as the catalyst (Table 1, Entry 4). 
Table 2. Synthesis of star $D$-sorbitol-PCL by ROP in the presence of Novozym 435 in the bulk and in $\mathrm{scCO}_{2}{ }^{\mathrm{a}}$

\begin{tabular}{|c|c|c|c|c|c|c|c|c|c|c|}
\hline \multirow[b]{2}{*}{ Entry } & \multirow[b]{2}{*}{ Solv. } & \multirow{2}{*}{$\begin{array}{l}\mathrm{N} 435^{\mathrm{b}} \\
(\mathrm{wt} \%)\end{array}$} & \multirow{2}{*}{$\begin{array}{l}\mathrm{t} \\
(\mathrm{h})\end{array}$} & \multicolumn{3}{|c|}{${ }^{1} \mathrm{H}$ NMR } & \multicolumn{2}{|c|}{ SEC-MALS } & \multirow{2}{*}{$\begin{array}{c}\text { SEC- } \\
\text { MALS/ } \\
1 \text { H NMR) } \\
{ }^{1} \text { SEC- } \\
N_{\text {arms }} \\
\text { MALS/NMR e }\end{array}$} & \multirow{2}{*}{$\begin{array}{c}\text { SEC } \\
\begin{array}{c}\text { Slope } \\
(\alpha)^{\mathrm{e}}\end{array}\end{array}$} \\
\hline & & & & $\begin{array}{c}\text { Conv. }^{\mathrm{c}} \\
(\%)\end{array}$ & $\begin{array}{l}D P_{\mathrm{n}} \\
\mathrm{NMR}_{\mathrm{c}} \\
(\mathrm{arm})\end{array}$ & $\begin{array}{c}M_{\mathrm{n}}^{\text {H-NMR c }} \\
(\mathrm{arm}) \\
\left(\mathrm{g} \mathrm{mol}^{-1}\right) \\
\end{array}$ & $\begin{array}{c}M_{\mathrm{n}}{ }^{\text {SEC-MALS }} \\
\left(^{\text {(star polymer })^{\mathrm{c}}}\right. \\
\left(\mathrm{g} \mathrm{mol}^{-1}\right)\end{array}$ & $\bigoplus^{\mathrm{d}}$ & & \\
\hline Entry 1 & \multirow{2}{*}{ Bulk } & 3 & 18 & $87 \%$ & 24 & 2700 & 5650 & 1.34 & 2.1 & 0.58 \\
\hline Entry 2 & & 10 & 7 & $91 \%$ & 29 & 3300 & 7800 & 1.36 & 2.4 & 0.58 \\
\hline Entry 3 & \multirow[b]{2}{*}{$\mathrm{scCO}_{2}$} & 3 & 24 & $96 \%$ & 28 & 3200 & 8800 & 1.24 & 2.7 & 0.57 \\
\hline Entry 4 & & 10 & 7 & $96 \%$ & 30 & 3400 & 10100 & 1.23 & 3.0 & 0.58 \\
\hline \multicolumn{11}{|c|}{$\begin{array}{l}\text { M: Monomer }(\varepsilon-\mathrm{CL}) \text {, I: Initiator }\left(D \text {-sorbitol). }{ }^{\mathrm{a}}[\mathrm{M}]:[\mathrm{I}]=52.6: 1 \text { based on } M_{\mathrm{n}}{ }^{\mathrm{targ}}=[\mathrm{M}]:[\mathrm{I}] \times M_{\varepsilon-\mathrm{CL}} \text { at } 100 \%\right. \\
\text { monomer conversion }=6000 \mathrm{~g} \mathrm{~mol}^{-1} \cdot{ }^{\mathrm{b}} \mathrm{N} 435=\text { Novozym } 435 \text { given in wt } \% \text { with respect to the weight of the } \\
\text { monomer. }{ }^{\mathrm{c}} \text { Determined by }{ }^{\mathrm{l}} \mathrm{H} \text { NMR. }{ }^{\mathrm{c}} \text { Degree of polymerisation and average molecular weight of arms } \\
\text { following Eq. S1 and S2, respectively. }{ }^{\mathrm{d}} \text { Molecular weight and polydispersity index }(\nexists) \text { determined by SEC- } \\
\text { MALS. }{ }^{\mathrm{d}} \text { Average number of arms estimated by SEC-MALS and }{ }^{1} \mathrm{H} \text { NMR following Eq. S4. }{ }^{\mathrm{e}} \text { Mark-Houwink } \\
\text { slope }(\alpha) \text { determined by SEC following Eq. S5. }\end{array}$} \\
\hline
\end{tabular}

Decreasing the supported enzyme loading from 10 to $3 \mathrm{wt} \%$ in $\mathrm{scCO}_{2}$ resulted in a decrease in molecular weight and increase in reaction time to reach $96 \%$ conversion (Table 2 Entry 4 vs. Entry 3, Figure S4 and Figure S6). The same trend was observed in the bulk (Table 2, Entry 2 vs. Entry 1). However, for $3 \mathrm{wt} \%$ enzyme loading in the bulk, the monomer to polymer conversion appeared to be incomplete (87\%, Table 2, Entry 1) and plateaued between $13-18 \mathrm{~h}$ (Figure S3). By contrast, the use of $\mathrm{scCO}_{2}$ with $3 \mathrm{wt} \%$ enzyme resulted in a higher molecular weight $\left(M_{\mathrm{n}}{ }^{\text {SEC-MALS }}=8800 \mathrm{~g} \mathrm{~mol}^{-1} v s . M_{\mathrm{n}}{ }^{\text {SEC-MALS }}=5650 \mathrm{~g} \mathrm{~mol}^{-1}\right)$ and slightly higher conversion $(96 \%, 24$ h vs. 87\% 18 h) (Table 2, Entry $3 v s$. Entry 1). The absolute average molecular weight and dispersity of the star polymers obtained by enzymatic catalysis were determined by SEC-MALS (Figure 3). 


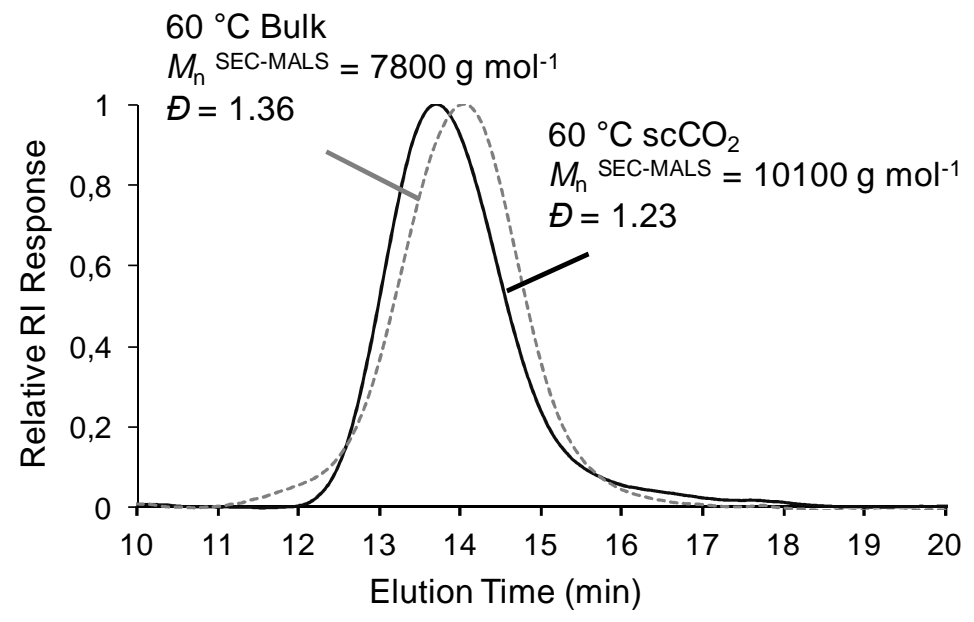

Figure 3. SEC-MALS traces overlay of star $D$-sorbitol-PCL catalysed by Novozym 435 (10 $\mathrm{wt} \%$ ) in the bulk and $\mathrm{scCO}_{2}$ at $60{ }^{\circ} \mathrm{C}$ (Table 2, Entry 2 vs. Entry 4).

For the polymerisation performed using $\mathrm{scCO}_{2}$ and enzyme, the star $D$-sorbitol-PCL resulted in slightly lower dispersities ( $Ð$ 1.23-1.24 vs 1.34-1.36) and higher molecular weights compared to reactions in the bulk (Table 2, Entry 3-4 vs. Entry 1-2). Usually, eROP of $\varepsilon-C L$ in the bulk results in a lower molecular weight polymer (typically $M_{\mathrm{n}}=3500-8500 \mathrm{~g} \mathrm{~mol}^{-1}$ ) with higher dispersity (typically $Ð \sim 2){ }^{31,62}$ Our data show very similar molecular weight but we observed lower dispersities $(\fallingdotseq=1.34-1.36)$ for star $D$-sorbitol-PCL made in the bulk. The narrow dispersity and higher molecular weight obtained in $\mathrm{scCO}_{2}$ are in good agreement with published reports on the synthesis of linear PCL by Novozym 435 in $\mathrm{scCO}_{2} .{ }^{51}$

After optimising the polymerisation conditions, the star structures were characterised in detail by NMR $\left({ }^{1} \mathrm{H}\right.$ and $\left.{ }^{31} \mathrm{P}\right)$, SEC (MALS and Mark-Houwink plot), MALDI-TOF-MS and DSC. The notation star $D$-sorbitol $\left[(\mathrm{PCL})_{\mathrm{n}} \mathrm{OH}\right]_{\mathrm{m}}$ will be used in the following discussion; $\mathrm{n}$ corresponds to the average amount of PCL repeat units per arm of $D$-sorbitol $\left(D P_{\mathrm{n}}(\operatorname{arms})\right.$ values given in Table 1 and Table 2) and m corresponds to the average number of arms. 


\subsection{Characterisation of star polymer architectures}

The influence of the catalyst and the reaction medium on the architecture of the star $D$ sorbitol-PCL polymers was studied by ${ }^{1} \mathrm{H}$ NMR spectroscopy (Figure 4). In principle, star $D$ sorbitol-PCL can have up to 6 PCL arms emanating from the 6 hydroxy groups of $D$-sorbitol. The multiplets at $\delta 1.64$ and $\delta 1.37 \mathrm{ppm}$ correspond to the methylene protons of the PCL backbone $\left(\mathrm{c}^{\prime}+\mathrm{c}^{\prime \prime}\right.$ and $\left.\mathrm{d}^{\prime}\right)$. The triplet at $\delta 2.29 \mathrm{ppm}$ corresponds to the methylene protons $\left(\mathrm{a}^{\prime}+\right.$ $\left.b^{\prime}\right)$ in $\alpha$-position of the carbonyl group whereas the signal at $\delta 4.05 \mathrm{ppm}$ corresponds to the protons ( $\left.\mathrm{e}^{\prime}\right)$. The methylene protons ( $\left.\mathrm{f}^{\prime}\right)$ in $\alpha$-position to the hydroxy end-groups of the PCL chains are visible at $\delta 3.63 \mathrm{ppm}($ Figure $4(\mathrm{~A})$ and (B)).

It is noteworthy that the signals corresponding to protons of the esterified primary carbon atoms appear between $\delta=4.0-4.4 \mathrm{ppm}$ and in the range of $\delta 5.0-5.5 \mathrm{ppm}$ for esterified secondary carbon atoms. Spectrum A corresponding to a sample synthesized in the melt using $\mathrm{Sn}(\mathrm{Oct})_{2}$ as the catalyst clearly shows the presence of protons adjacent to secondary esterified hydroxy groups $(5-5.5 \mathrm{ppm})$ whereas these resonances are not visible in spectrum B corresponding to a sample synthesised in $\mathrm{CO}_{2}$ by enzyme catalysis, indicating a high degree of functionalisation of secondary hydroxy groups when using a metal catalyst, and a low degree of functionalisation of secondary hydroxy groups when using enzyme catalysis. The resonances of pendant protons on the sorbitol core next to residual hydroxy groups are shifted to around $4 \mathrm{ppm}$ and overlap with resonances from the polymer backbone. However, due to a poor signal to noise ratio for the resonances of the protons of sorbitol which are located at the core of the structure, quantification based on the sorbitol signals from ${ }^{1} \mathrm{H}$ NMR is not-reliable (see Insets Figure 4). 


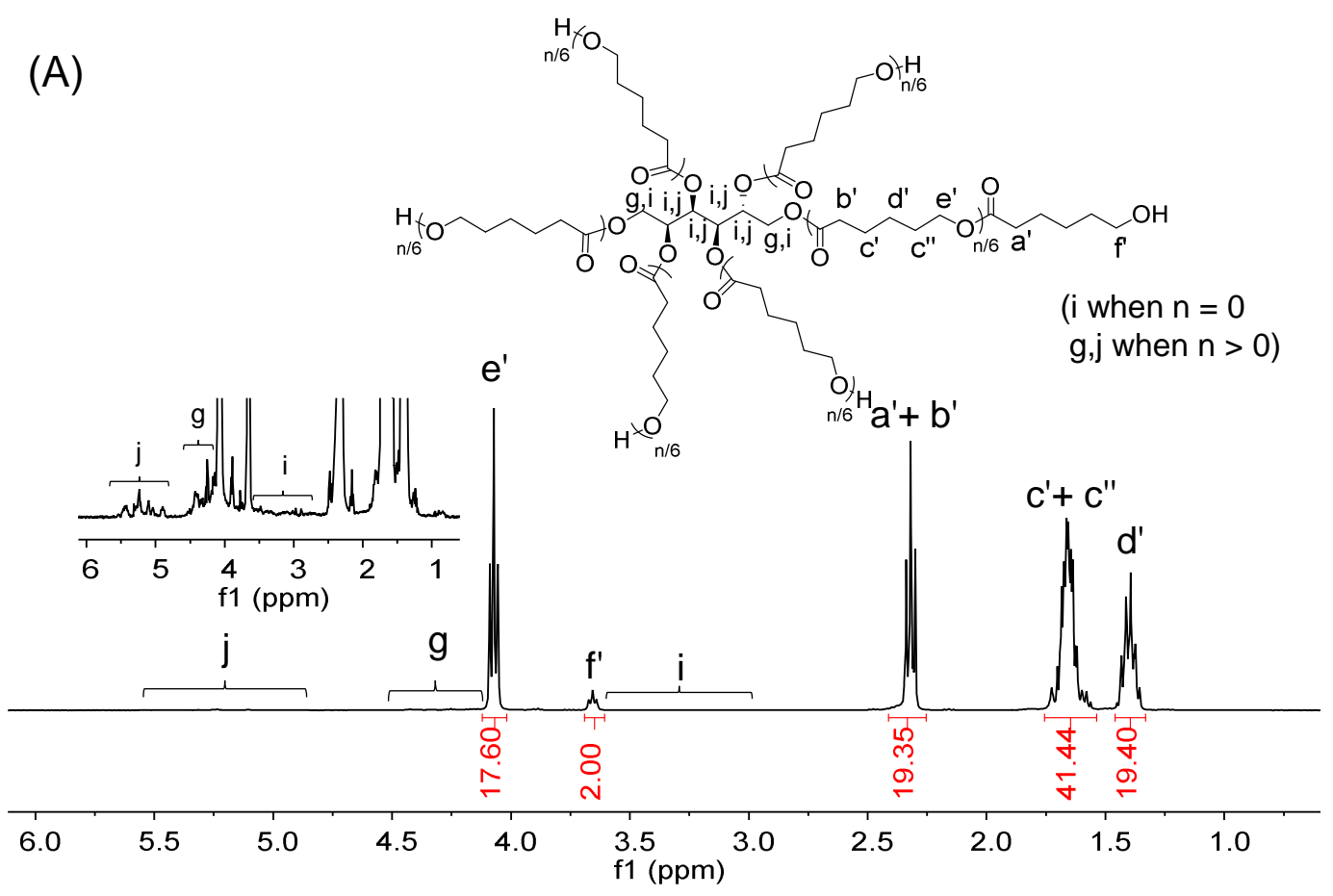

(B)

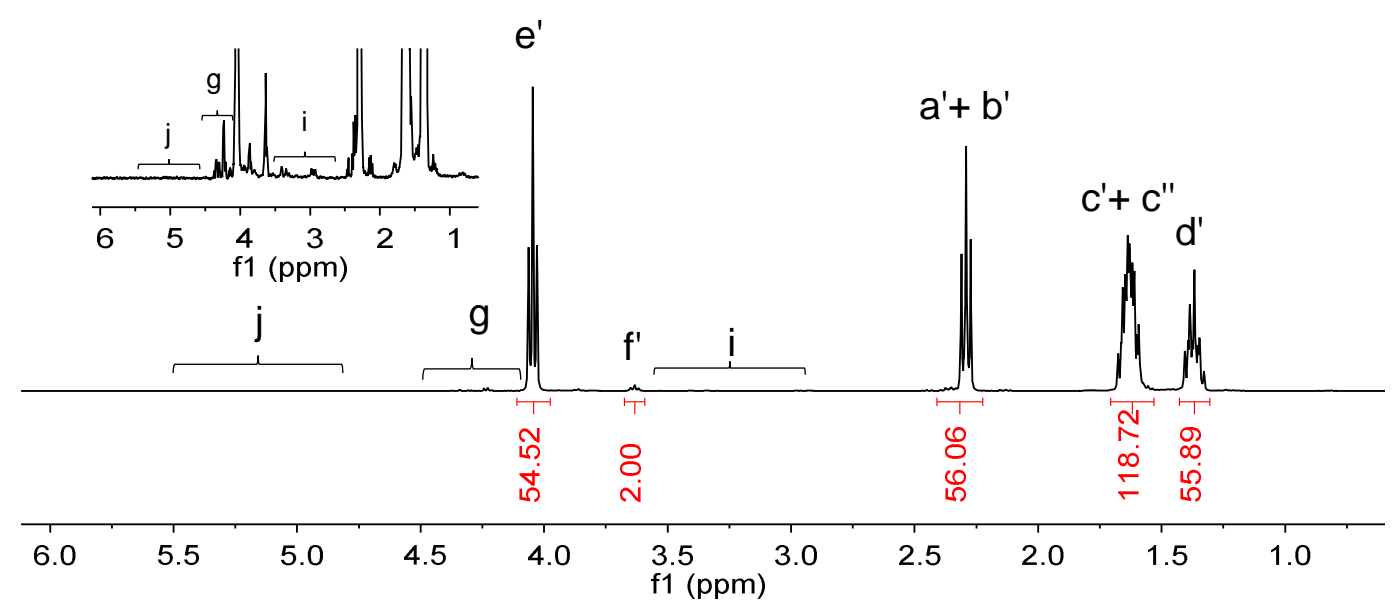

Figure 4. ${ }^{1} \mathrm{H} \quad \mathrm{NMR}$ spectra $\left(\mathrm{CDCl}_{3}, 400 \mathrm{MHz}\right)$ of (A) $\mathrm{Sn}(\mathrm{Oct})_{2}$ catalysed $D$ sorbitol $\left[(\mathrm{PCL})_{9.7} \mathrm{OH}\right]_{\mathrm{m}}$ in the bulk (Table 1, Entry 3) and (B) Novozym 435 catalysed $D$ sorbitol $\left[(\mathrm{PCL})_{28} \mathrm{OH}\right]_{\mathrm{m}}$ in $\mathrm{scCO}_{2}$ (Table 2, Entry 3). The inset shows the enlarged signals corresponding to the sorbitol core.

The degree of polymerisation, $D P_{\mathrm{n}}{ }^{\mathrm{NMR}}$ (arm) and number average molecular weight of each $\operatorname{arm}, M_{\mathrm{n}}{ }^{\mathrm{H}-\mathrm{NMR}}(\operatorname{arm})$, were calculated using equation $(\mathrm{S} 1)$ and (S2) for a representative 
sample star $D$-sorbitol[(PCL) $\left.{ }_{9.7}-\mathrm{OH}\right]_{\mathrm{m}}$ (Table 1, Entry 3 and Figure 4(A)) are 9.7 and $1100 \mathrm{~g}$ $\mathrm{mol}^{-1}$, respectively. In general, the $M_{\mathrm{n}}{ }^{\mathrm{H}-\mathrm{NMR}}$ (arm) of star $D$-sorbitol-PCL synthesised using $\mathrm{Sn}(\mathrm{Oct})_{2}\left(1100-1290 \mathrm{~g} \mathrm{~mol}^{-1}\right.$, Table 1) were lower than those obtained with Novozym 435 (2700-3400 $\mathrm{g} \mathrm{mol}^{-1}$, Table 2).

Since SEC-MALS measurements give access to the absolute number average molecular mass of star $D$-sorbitol-PCL $\left(M_{\mathrm{n}}^{\text {SEC-MALS }}\right.$ (star polymer)), the average number of arms $\left(N_{\text {arms }}\right.$ SECMALS/NMR ) can be estimated by combining this information with the $M_{\mathrm{n}}{ }^{\mathrm{H}-\mathrm{NMR}}$ (arm) (as $N_{\text {arms }}$ ${ }^{\text {SEC-MALS/NMR }}=M_{\mathrm{n}}{ }^{\text {SEC-MALS }}($ star polymer $\left.) / M_{\mathrm{n}}{ }^{\text {H-NMR }}(\operatorname{arm})\right)$. Accordingly, the star $D$-sorbitolPCL polymers synthesised using $\operatorname{Sn}(\mathrm{Oct})_{2}$ exhibit $N_{\mathrm{arms}}{ }^{\text {SEC-MALS/NMR }}=5.1$ in the bulk and $N_{\text {arms }}{ }^{\text {SEC-MALS/NMR }}=4.9$ in $\mathrm{scCO}_{2}$ (Table 1, Entry 3 vs. Entry 4). Interestingly, polymerisations performed employing enzyme catalysis resulted into a lower number of arms, $N_{\text {arms }}{ }^{\text {SEC-MALS/NMR }}=2.4$ and 3.0 (Table 2, Entry 2 and Entry 4 ) in the bulk and in $\mathrm{scCO}_{2}$, respectively. A lower number of arms observed with eROP may be related to the regioselectivity of Novozym 435 since the eROP initiated from primary alcohols may be favoured in comparison to secondary alcohols. ${ }^{63,64}$ Whatever the enzyme loading, a slightly higher $N_{\text {arms }}$ SEC-MALS/NMR resulted for star PCL synthesised in $\mathrm{scCO}_{2}$ compared to the analogues made in the bulk $\left(N_{\text {arms }}{ }^{\text {SEC-MALS/NMR }}=2.1\right.$ vs. 2.7 and 2.4 vs. 3.0, respectively (Table 2 Entry 1 vs. Entry 3 and Entry 2 vs. Entry 4).

For polymerisations in the presence of $\mathrm{Sn}(\mathrm{Oct})_{2}$, all the star-PCL polymers exhibit narrow molecular weight distributions $(\nexists=1.03-1.12$, Table 1) according to SEC-MALS analysis. Such low dispersities suggest a uniform sample of star-PCL, where the number of arms is the same. The length of the arms of one individual star polymer may be the same or of different length, but with a uniform architecture throughout the sample.

Higher dispersities are observed with Novozym 435 as the catalyst $(~ Ð=1.23-1.36$, Table 2$)$. These higher dispersities could be caused by transesterification side reactions occurring 
during eROP. Macrocycles formed by back-biting (intramolecular transesterification) or linear PCL initiated by water (mainly originating from the enzyme) can also be present in small amounts in the final star polymers. ${ }^{50,65}$ In addition, since Novozym 435 is regioselective, ${ }^{66}$ initiation from the primary hydroxy groups of $D$-sorbitol is expected to be faster than initiation from the secondary hydroxy groups, implying that there will be arms with different lengths (i.e., shorter arms from the secondary alcohols of $D$-sorbitol) and leading to star PCL with a miktoarm star architecture.

\subsection{Mark-Houwink plot for star-branched polymer}

The structure of the star polymers can be confirmed by SEC analysis with an RI and a viscosity detector using the Mark-Houwink relationship. The slope $(\alpha)$ of the doublelogarithmic Mark-Houwink plots, derived for star $D$-sorbitol-PCL from $[\eta]=\mathrm{K} \times M^{\alpha}$, where $[\eta]$ is intrinsic viscosity, $M$ is molecular weight, and $\alpha$ and $\mathrm{K}$ are the Mark-Houwink constants, is related to the branching of the polymers (Figure S7). An $\alpha$-value between 0.1 to 0.6 is representative of star polymers and a value from 0.6 to 1 corresponds to linear coil structures. ${ }^{67,68,69}$ Branched polymers have a higher segment density compared to linear polymers of equivalent molecular weight, resulting in a decrease in intrinsic viscosity. ${ }^{70,71}$ All the $D$-sorbitol-PCL polymers synthesised by Novozym 435 and $\operatorname{Sn}(\text { Oct })_{2}$ have $\alpha$-values between 0.27 to 0.58 , which is in good accordance with a star like architecture of the polymers. However, it is worth noting that star $D$-sorbitol-PCL polymers synthesised with $\mathrm{Sn}(\mathrm{Oct})_{2}$ either in the bulk or in $\mathrm{scCO}_{2}$ have a slightly lower intrinsic viscosity in comparison to those obtained with Novozym 435 (Figure S7). We hypothesise that this shows a lower number of arms for the star polymers synthesised by enzyme catalysis compared to those synthesised using $\mathrm{Sn}(\mathrm{Oct})_{2}$. The $\alpha$-values of the $D$-sorbitol-PCL polymers synthesised by 
Novozym 435 (0.57-0.58; Table 2$)$ are close to 0.6 indicating structures in between a star-like and a linear-like topology. This observation might suggest structures composed of two main arms with a low amount of shorter arms radiating from the secondary $D$-sorbitol -OH groups. Star $D$-sorbitol polymers synthesised with $\mathrm{Sn}(\mathrm{Oct})_{2}$ either in the bulk or in $\mathrm{scCO}_{2}$ show lower values of $\alpha(0.27-0.39$; Table 1$)$ which indicates a more branched structure and thus a larger number of arms.

MALDI-TOF analyses were performed in order to further investigate the synthesised star polymers.

\subsection{MALDI-TOF MS}

A semi-quantitative investigation by MALDI-TOF-MS gave insights into the molecular structure of star $D$-sorbitol-PCL. The mass spectrum of star $D$-sorbitol-PCL synthesised using $\mathrm{Sn}(\mathrm{Oct})_{2}$ regardless of the solvent medium showed one distribution where the signals were separated by $114.14 \mathrm{~m} / \mathrm{z}$ corresponding to the mass of the $\varepsilon$-CL repeating units (Figure 5). All signals were assigned to PCL chains initiated by $D$-sorbitol with $\mathrm{K}^{+}$as the cation. These results confirm the formation of star $D$-sorbitol-PCL without side reactions. The inset (Figure 5) shows the signals at $\mathrm{m} / \mathrm{z}=5015.3,5129.4$ and 5243.6, which represent molecular masses of the $\mathrm{K}^{+}$adduct of $D$-sorbitol attached to 42,43 and $44 \varepsilon$-CL units, respectively. 


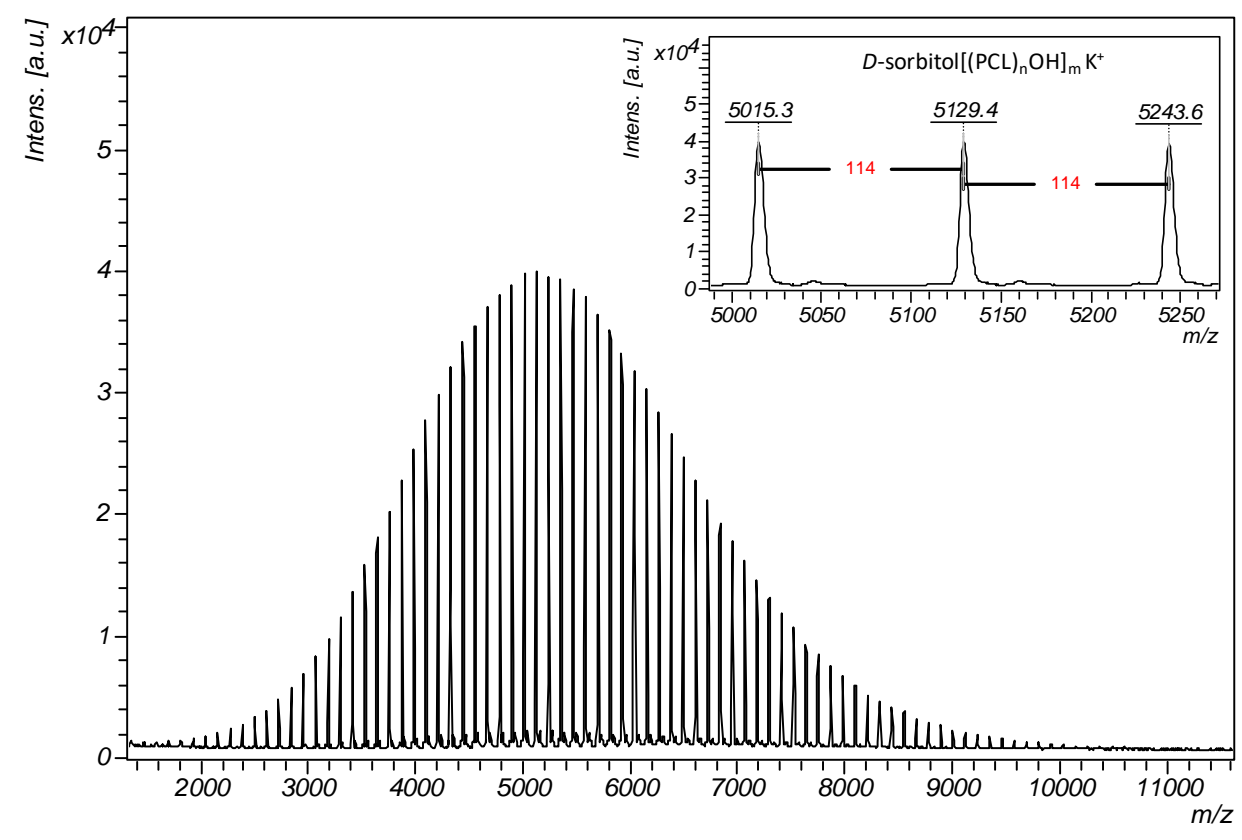

Figure 5. MALDI-TOF mass spectrum of $D$-sorbitol[ $\left.(\mathrm{PCL})_{9.7} \mathrm{OH}\right]_{\mathrm{m}}$ synthesised in the bulk in the presence of $\mathrm{Sn}(\mathrm{Oct})_{2}$ (Table 1, Entry 3). The MALDI-TOF spectrum was acquired in linear mode.

All the signals in the mass spectrum of star $D$-sorbitol[(PCL $\left.)_{28} \mathrm{OH}_{\mathrm{m}}\right]$ (Table 2, Entry 3) catalysed by $3 \mathrm{wt} \%$ Novozym 435 in $\mathrm{scCO}_{2}$ correspond to polymers with the $\varepsilon$-CL repeat unit as well (Figure 6). The main population (P1) is composed of $\mathrm{K}^{+}$adducts of $D$-sorbitol initiated PCL. For instance, the signal at $\mathrm{m} / \mathrm{z}=3074.9$ in the inset corresponds to the $\mathrm{K}^{+}$ adduct of $D$-sorbitol attached to $25 \varepsilon$-CL units $\left(\left[D \text {-sorbitol }\left[(\mathrm{PCL}){ }_{25} \mathrm{OH}_{\mathrm{m}}\right]+\mathrm{K}\right]^{+}\right)$. For both syntheses in the bulk and in $\mathrm{scCO}_{2}$, three distributions were observed in the MALDI-TOF spectra of star $D$-sorbitol $\left[(\mathrm{PCL})_{\mathrm{n}} \mathrm{OH}\right]_{\mathrm{m}}$ synthesised using Novozym 435 . In addition to the main population (P1), a second population (P2) corresponding to PCL initiated by water (linear HOOC-PCL-OH) and a third population (P3) corresponding to PCL macrocycles formed by the back-biting side-reaction ${ }^{62}$ were present in the low molecular mass region $(\mathrm{m} / \mathrm{z}$ $=1000-3000$, Figure 6, inset). 


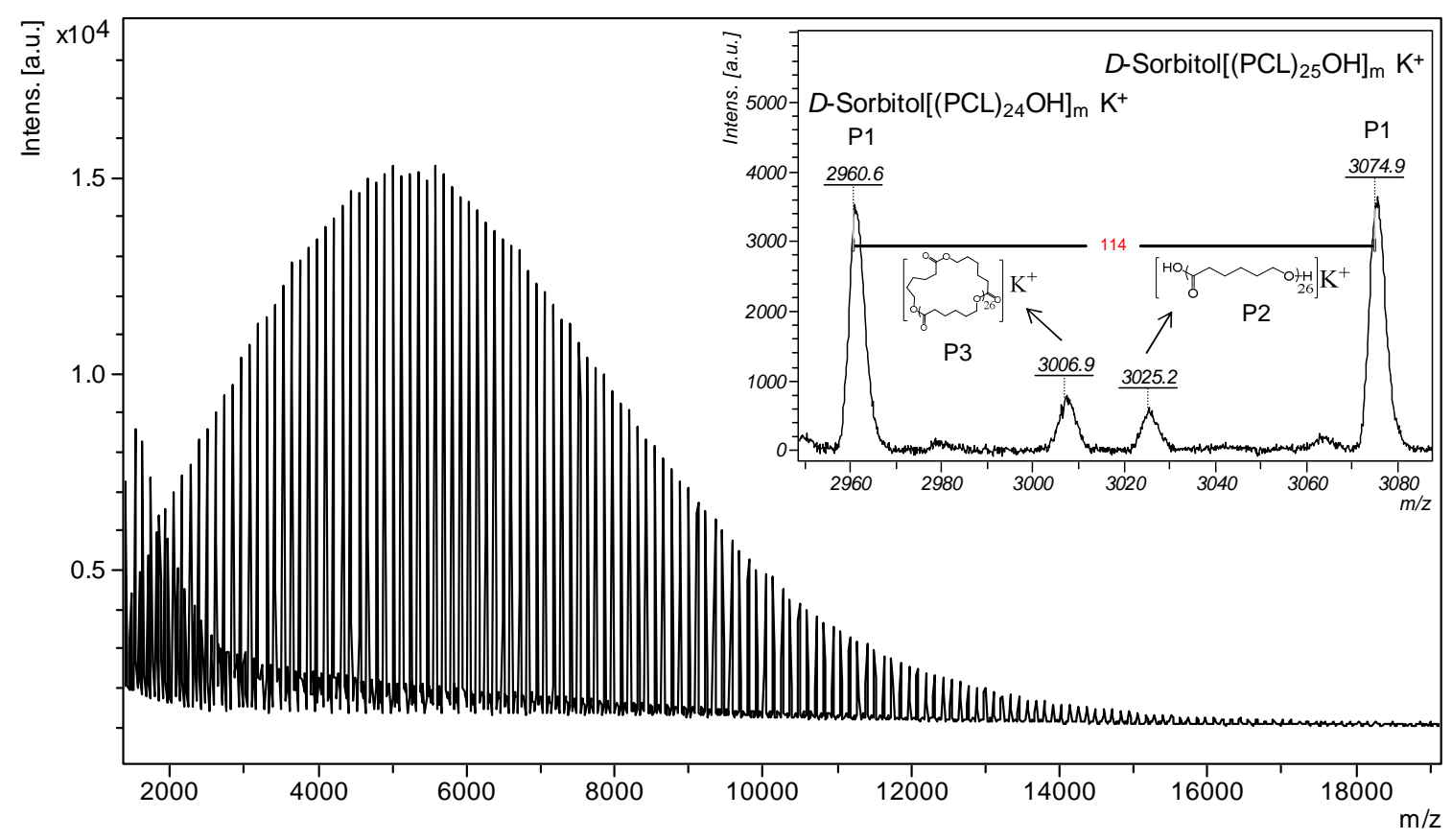

Figure 6. MALDI-TOF mass spectrum of $D$-sorbitol[(PCL $\left.)_{28} \mathrm{OH}\right]_{\mathrm{m}}$ synthesised in presence of 3 wt $\%$ Novozym 435 using $\mathrm{scCO}_{2}$ (Table 2, Entry 3). The $\mathrm{m} / \mathrm{z}$ values given in the inset correspond to the main population $D$-sorbitol $\left[(\mathrm{PCL})_{\mathrm{n}} \mathrm{OH}\right]_{\mathrm{m}} \mathrm{K}^{+}$. Additional populations (P2 and P3) observed in the low molecular weight region are assigned to side-products related to PCL initiated by water and macrocycles.

Thus, MALDI-TOF analysis revealed the formation of a mixture of structures for the star $D$ sorbitol-PCL synthesised using Novozym 435 as the catalyst (Figure 6) and therefore the ratio $M_{\mathrm{n}}{ }^{\text {SEC-MALS }}$ (star polymer) $/ M_{\mathrm{n}}{ }^{\mathrm{H}-\mathrm{NMR}}(\operatorname{arm})$ is not a fully reliable estimation of the number of arms. In order to better understand the structure of star PCL, in particular, star PCL synthesised using Novozym 435 as the catalyst, the polymers were characterised by a phosphitylation $/{ }^{31}$ P NMR method. 


\subsection{Quantifying the number of arms by a phosphitylation $/{ }^{31}$ P NMR method}

The quantitative investigation of the number of arms $\left(N_{\mathrm{arms}}\left({ }^{31} \mathrm{P}\right)\right)$, the number average molecular weight of the $\operatorname{arms}\left(M_{\mathrm{n}}^{\mathrm{P}-\mathrm{NMR}}(\operatorname{arm})\right)$, the molecular weight of the star polymer $\left(M_{\mathrm{n}}^{\mathrm{P}-}\right.$ ${ }^{\mathrm{NMR}}$ (star polymer)) and the percentage of linear PCL chains present in star $D$-sorbitol-PCL was performed by the phosphitylation method developed by Spyros et al. ${ }^{72}$ This method utilises 2-chloro-4,4,5,5-tetramethyldioxaphospholane (Cl-TMDP) as a phospholane reagent and cyclohexanol as an internal standard for subsequent ${ }^{31} \mathrm{P}$ NMR analysis.

The ${ }^{31} \mathrm{P}$ NMR analysis of $D$-sorbitol was performed as a reference for the phospholane ester of $D$-sorbitol, the primary hydroxy groups $\left(1^{\circ} \text {, triplet, }-\mathrm{CH}_{2} \mathrm{OP}-, \delta=147.0-148.6 \mathrm{ppm}\right)^{73}$ can be distinguished from the secondary hydroxy groups $\left(2^{\circ}\right.$, doublet, $-\mathrm{CHOP}-, \delta=145.5-147.0$ $\mathrm{ppm})^{73}$ (Scheme S2, Figure S8 (A), (B)). Moreover, the signal corresponding to the primary hydroxy groups of the PCL arm of star D-sorbitol-PCL polymer, exhibits a different chemical shift $\left(1^{\circ}\right.$, triplet, -PCL-OP, $\left.\delta=\sim 147.02\right)$ than those originating from the $D$-sorbitol core (Figure 7 (A)-(C)). A downfield shift was also observed for any residual hydroxy group of the $D$-sorbitol core present in the star PCL for both catalytic systems (Figure 7 (B)-(C) vs. Figure 7 (A)). A phosphitylated carboxy acid group has a different chemical shift range (COOP-, $\delta=133.0-136.6 \mathrm{ppm}$ ) than hydroxy groups. ${ }^{73}$ Hence, it is possible to identify the end groups of the water initiated linear PCL.

The representative ${ }^{31} \mathrm{P}$ NMR spectrum of the star $D$-sorbitol[(PCL $\left.)_{9.7} \mathrm{OH}\right]_{\mathrm{m}}$ synthesised using $\mathrm{Sn}(\mathrm{Oct})_{2}$ in the bulk (Table 1, Entry 3) shows no signals corresponding to -COOP- (Figure 7 (B)), which is in corroboration with MALDI-TOF MS data confirming the absence of water initiated linear PCL in the samples prepared using $\mathrm{Sn}(\mathrm{Oct})_{2}$ as a catalyst. The corresponding inverse gated proton-decoupled ${ }^{31} \mathrm{P}$ NMR spectra were recorded in the presence of an internal standard (cyclohexanol) for quantification (Figure S9 A). The number of arms, $N_{\text {arms }}\left({ }^{31} \mathrm{P}\right.$ ), of star $D$-sorbitol[(PCL $\left.)_{9.7} \mathrm{OH}\right]_{\mathrm{m}}$ corresponds to the number of hydroxy groups of $D$-sorbitol that 
have effectively initiated the ROP of $\varepsilon$-CL. It was evaluated by comparing the number of phosphitylated PCL chain ends $\left(\int\right.$ PCL-OP $)$ with the total number of phosphitylated hydroxy groups in the sample (Equation (1) $)^{26}$ :

$$
N_{\mathrm{arms}}\left({ }^{31} \mathrm{P}\right)=\frac{\int_{\mathrm{PCL}-\mathrm{OP}}}{\int_{\left(1^{\circ}+2^{\circ}\right)}+\int_{\mathrm{PCL}-\mathrm{OP}}} \times 6
$$

The total number of phosphitylated groups in the star polymer corresponds to the residual phosphitylated hydroxy groups $\left(1^{\circ}+2^{\circ}\right)$ on the $D$-sorbitol core and the phosphitylated hydroxy chain ends of the PCL arms (PCL-OP), and 6 corresponds to the total amount of hydroxy groups of the initiator. The absence of signals resulting from primary hydroxy groups of the core in star $D$-sorbitol[(PCL $\left.)_{9.7} \mathrm{OH}\right]_{\mathrm{m}}$ implies that all primary hydroxy group initiate the ROP of $\varepsilon$-CL (two growing arms). In contrast, $23 \%$ of the secondary hydroxy groups of the core are still present in the star polymer indicating three growing arms from secondary hydroxy groups in average (Figure S9(A)). This presence of residual secondary hydroxy groups could be explained by the steric hindrance resulting from adjacent PCL arms. An average of five arms was obtained for star $D$-sorbitol[(PCL $\left.)_{9.7-11.3} \mathrm{OH}\right]_{5}$ catalysed by $\mathrm{Sn}(\mathrm{Oct})_{2}$ both in the bulk and in $\mathrm{scCO}_{2}$ (Table 3).

For the polymerisation using enzyme catalysis regardless of the reaction medium, the ${ }^{31} \mathrm{P}$ NMR analysis of the star $D$-sorbitol[(PCL) $24-30 \mathrm{OH}]_{\mathrm{m}}$ sample (Table 2) shows resonances associated with carboxy acid groups (singlet,-COOP, $\delta=134.74 \pm 0.01 \mathrm{ppm}$ ), corresponding to linear PCL (Figure S10-S11). It correlates well with MALDI-TOF analysis of these samples (e.g. Figure 6), confirming the presence of low molecular weight linear PCL chains initiated by water. However, the quantity of linear PCL chains present in star D-sorbitol-PCL samples synthesised by enzyme catalysis was very low (1.4 -11.3\%) (Equation (S8), Table 4 \& Table S2, Figure S10-S11). 
(A) D-Sorbitol + Cl-TMDP

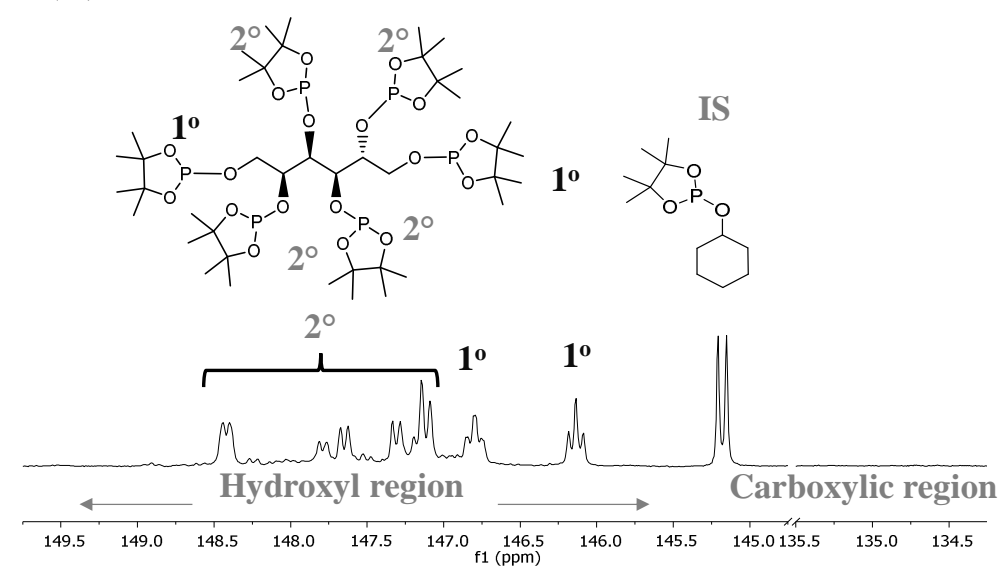

(B) $D$-sorbitol $\left[(\mathrm{PCL})_{9.6} \mathrm{OH}\right]_{\mathrm{m}}+$ Cl-TMDP

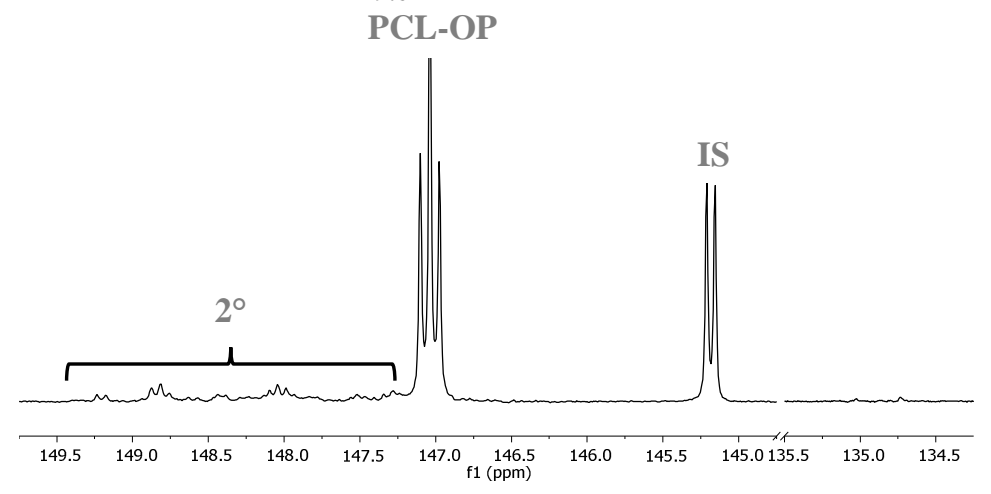

(C) D-sorbitol $\left[(\mathrm{PCL})_{29} \mathrm{OH}\right]_{\mathrm{m}}+\mathrm{Cl}$-TMDP

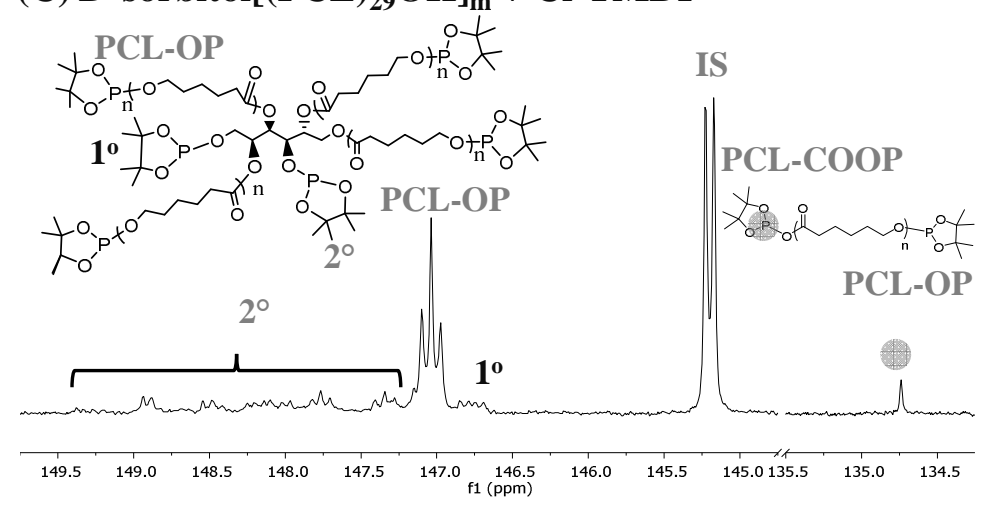

Figure 7. ${ }^{31} \mathrm{P}$ NMR spectra without decoupling of phosphitylated (A) $D$-sorbitol, (B) star $D$ sorbitol[(PCL) $\left.{ }_{9.7} \mathrm{OH}\right]_{\mathrm{m}}$ (Table 1, Entry 3) showing residual secondary hydroxy groups on the $D$-sorbitol core and (C) star $D$-sorbitol $\left[(\mathrm{PCL})_{28} \mathrm{OH}\right]_{\mathrm{m}}$ (Table 2, Entry 3) showing residual primary and secondary hydroxy groups on $D$-sorbitol alongside linear PCL. IS: internal standard (cyclohexanol). It should be noted from Figure S8 that there are minor additional peaks that arise after the phosphitylation process and appear in the region of the $2^{\circ}$ hydroxyl. 
Table 3. Determination of the number of arms and the molecular weight by ${ }^{31} \mathrm{P}$ NMR for star D-sorbitol-PCL synthesised in the presence of $\mathrm{Sn}(\mathrm{Oct})_{2}$.

\begin{tabular}{lcccc}
\hline & \multicolumn{3}{c}{${ }^{31} \mathrm{P}$ NMR (Phosphitylation) } \\
\hline Sample & $N_{\text {arms }}\left({ }^{31} \mathrm{P}\right)^{\mathrm{a}}$ & $\begin{array}{c}M_{\mathrm{n}}{ }^{\text {P-NMR }} \\
(\operatorname{arm}) \\
\left(\mathrm{g} \mathrm{mol}^{-1}\right)\end{array}$ & $\begin{array}{c}M_{\mathrm{n}}{ }^{\text {P-NMR }} \\
(\text { star polymer })^{\mathrm{c}} \\
\left(\mathrm{g} \mathrm{mol}^{-1}\right)\end{array}$ & Notation of samples in Table 1 \\
\hline Entry 1 & 5.0 & 1250 & 6300 & star $D$-sorbitol[(PCL) $\left.)_{11.3} \mathrm{OH}\right]_{5.0}$ \\
Entry 2 & 4.8 & 1190 & 5750 & star $D$-sorbitol[(PCL $\left.)_{11.0} \mathrm{OH}\right]_{4.8}$ \\
Entry 3 & 5.1 & 1100 & 5600 & star $D$-sorbitol[(PCL $\left.)_{9.7} \mathrm{OH}\right]_{5.1}$ \\
Entry 4 & 5.0 & 1300 & 6500 & star $D$-sorbitol[(PCL $\left.)_{11.0} \mathrm{OH}\right]_{5.0}$ \\
\hline
\end{tabular}

${ }^{a}$ Average number of arms quantified following Eq. (1) and the corresponding inverse gated decoupled ${ }^{31}$ P NMR spectra (Figure S9).

${ }^{b}$ Number average molecular weight of arms determined following Eq. (S6).

${ }^{\mathrm{c}}$ Molecular weight of star polymer determined following Eq. (S7).

The $N_{\text {arms }}\left({ }^{31} \mathrm{P}\right)$ for enzyme catalysed star PCL was evaluated accounting for the water initiated linear PCL chains (HOOC-PCL-OH) (Equation (2)):

$$
N_{\text {arms }}\left({ }^{31} \mathrm{P}\right)=\frac{\int_{\mathrm{PCL}-O \mathrm{P}}-\int_{\mathrm{PCL}-\mathrm{COOP}}}{\int_{\left(1^{\circ}+2^{\circ}\right)}+\int_{\mathrm{PCL}-\mathrm{OP}}-\int_{\mathrm{PCL}-\mathrm{COOP}}} \times 6
$$

Table 4. Quantification of the number of arms and the molecular weight by ${ }^{31} \mathrm{P}$ NMR for $D$ sorbitol-PCL synthesised in the presence of Novozym 435.

\begin{tabular}{|c|c|c|c|c|c|}
\hline \multicolumn{6}{|c|}{${ }^{31}$ P NMR (Phosphitylation) } \\
\hline Sample & $\begin{array}{l}N_{\text {arms }} \\
\left({ }^{31} \mathrm{P}\right)^{\mathrm{a}}\end{array}$ & $\begin{array}{l}\% \mathrm{COOH}^{\mathrm{b}} \\
\text { (linear } \\
\text { chains) }\end{array}$ & $\begin{array}{c}M_{\mathrm{n}}^{\mathrm{P}-\mathrm{NMR} \mathrm{c}} \\
(\text { arm }) \\
\left(\mathrm{g} \mathrm{mol}^{-1}\right)\end{array}$ & $\begin{array}{l}M_{\mathrm{n}}{ }^{\text {P-NMR }} \\
(\text { star polymer) } \\
{ }^{\mathrm{d}}\left(\mathrm{g} \mathrm{mol}^{-1}\right)\end{array}$ & Notation of samples in Table 2 \\
\hline Entry 1 & 3.1 & 1.4 & 2000 & 6200 & star $D$-sorbitol $\left[(\mathrm{PCL})_{24} \mathrm{OH}\right]_{3.1}$ \\
\hline Entry 2 & 3.3 & 5.2 & 3200 & 10600 & star $D$-sorbitol $\left[(\mathrm{PCL})_{29} \mathrm{OH}\right]_{3.3}$ \\
\hline Entry 3 & 3.2 & 5.4 & 3000 & 9600 & star $D$-sorbitol $\left[(\mathrm{PCL})_{28} \mathrm{OH}\right]_{3.2}$ \\
\hline Entry 4 & 2.9 & 11.3 & 2900 & 8400 & star $D$-sorbitol $\left[(\mathrm{PCL})_{30} \mathrm{OH}\right]_{2.9}$ \\
\hline
\end{tabular}

${ }^{a}$ Average number of arms quantified following Eq. (2) and the corresponding inverse gated decoupled

${ }^{31}$ P NMR spectra (Figure S10 and Figure S11).

${ }^{\mathrm{b}}$ Amount of linear PCL chains quantified following Eeq. (S8).

${ }^{\mathrm{c}}$ Number average molecular weight of arms determined following Eq. (S6).

${ }^{\mathrm{d}}$ Molecular weight of star polymer determined following Eq. (S7).

Following equation (2) the $N_{\text {arms }}\left({ }^{31} \mathrm{P}\right)$ for all the star D-sorbitol-PCL synthesised using Novozym 435 was about 3 regardless of the catalyst loading and the reaction medium (Table 
4). The $N_{\text {arms }}{ }^{\text {SEC-MALS/NMR }}$ values are slightly lower than the $N_{\text {arms }}\left({ }^{31} \mathrm{P}\right)$ values because SECMALS cannot account for the presence of linear PCL in the star polymer samples. In ${ }^{31} \mathrm{P}$ NMR analysis of Novozym 435 catalysed star $D$-sorbitol[(PCL $\left.)_{28} \mathrm{OH}\right]_{\mathrm{m}}$ (Table 2, Entry 3, Figure S11 (A)), the resonances corresponding to residual hydroxy groups of $D$-sorbitol core show that $72 \%$ of the primary hydroxy groups initiate ROP of $\varepsilon$-CL (1.5 growing arms in average) and about $45 \%$ of the secondary hydroxy groups initiate ROP of $\varepsilon$-CL (1.8 growing arms in average). This indicates that the Novozym 435 catalyst is preferentially initiating the eROP of $\varepsilon$-CL from the primary hydroxy groups of $D$-sorbitol but Novozym 435 is not completely regioselective towards primary alcohols under the reaction conditions studied. The overall number of arms determined for star $D$-sorbitol $\left[(\mathrm{PCL})_{28} \mathrm{OH}\right]_{3.2}$ sample in this way is 3.2 (Table 4, Entry 3).

The $M_{\mathrm{n}}{ }^{\mathrm{P}-\mathrm{NMR}}$ (arm) determined by ${ }^{31} \mathrm{P}$ NMR (Table 3 and Table 4) are in good agreement with the results from $M_{\mathrm{n}}{ }^{\mathrm{H}-\mathrm{NMR}}$ (arm) analysis (Table 1 and Table 2). An average number of arms of 5 is determined by both the ${ }^{31} \mathrm{P}$ and ${ }^{1} \mathrm{H}$ NMR analyses in addition to the narrow dispersities observed by SEC-MALS $(Ð=1.03-1.12$, Table 1$)$ and the uniform distribution (uniform Gaussian curve) observed by MALDI-TOF confirm the controlled synthesis of well-defined, regular star polymers in the presence of $\mathrm{Sn}(\mathrm{Oct})_{2}$ in the bulk and in $\mathrm{scCO}_{2}$ (Figure 8(A)). When using Novozym 435 as the catalyst, a lower value of 3 for the average number of arms, higher molecular weights of the arms, and slightly higher dispersities $(\nexists=$ 1.23-1.36) were observed compared to using $\mathrm{Sn}(\mathrm{Oct})_{2}$. This indicates that a lower number of hydroxy groups of $D$-sorbitol initiate the eROP leading to less regular star architectures (Figure 8 (B)). It is important to state that detailed analysis of the phosphitylation process (Figure S8 (B)) does show that the process is unlikely to be fully quantitative on $D$-sorbitol and that there are some minor impurities arising from other species that are revealed in the $2^{\circ}$ peaks. These will, of course, contribute to the ${ }^{31} \mathrm{P}$ NMR spectra of the star polymers (Figure 
7) and introduce some error into our calculations of the $N_{\text {arms }}\left({ }^{31} \mathrm{P}\right)$ but nevertheless, these data corroborate the differences observed in the products arising from tin catalysis and from the enzyme.

(A) Regular star polymer by $\mathrm{Sn}(\mathrm{Oct})_{2}$

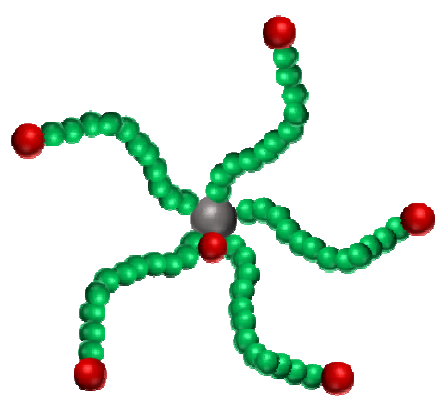

(B) Miktoarm star polymer by Novozym 435

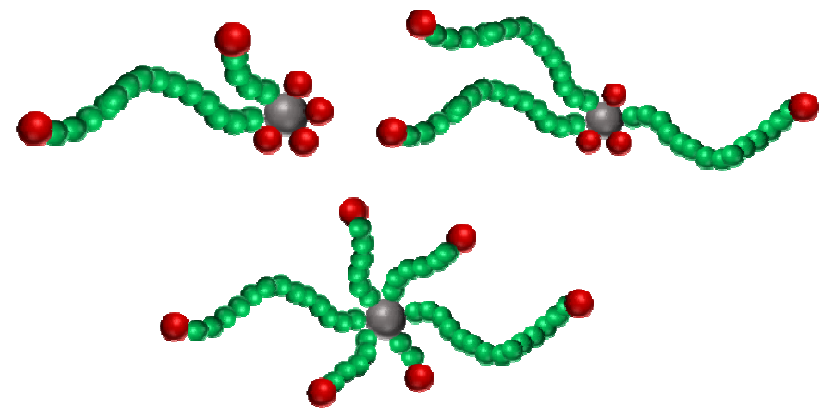

Figure 8. Schematic representation of star D-sorbitol-PCL synthesised by (A) $\operatorname{Sn}(\mathrm{Oct})_{2}$ giving regular star polymers with 5 arms and by (B) Novozym 435 yielding a mixture of

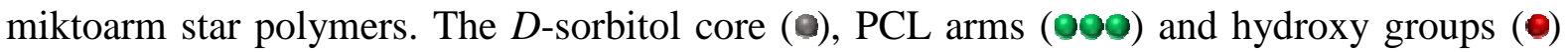
are presented.

\subsection{DSC (in $\left.\mathbf{N}_{2}\right)$}

DSC was employed to investigate the thermal properties of polyol-PCL $\left(M_{\mathrm{n}}{ }^{\text {SEC-MALS }}=6000\right.$ $\mathrm{g} \mathrm{mol}^{-1}$, Table S1) synthesised in the presence of $\mathrm{Sn}(\mathrm{Oct})_{2}$ and star D-sorbitol-PCL synthesised using Novozym 435 (Table 2). As expected, the polymers were semi-crystalline. The melting point of the polyol-PCL decreases with an increasing number of arms (Figure 9), which may hinder the formation of crystalline domains in PCL (Figure S12). This result is in agreement with a previous report by Endo et al. ${ }^{19}$ who observed that a four-arm star PCL exhibited the lowest $T_{\mathrm{m}}$ when compared to star PCL of similar molecular weights with three or two arms.

The melting temperature $\left(T_{\mathrm{m}}\right)$ of the regular star D-sorbitol-PCL synthesised using $\mathrm{Sn}(\mathrm{Oct})_{2}$ as the catalyst in the bulk $\left(N_{\text {arms }}\left({ }^{31} \mathrm{P}\right)=5.1, T_{\mathrm{m}}=35{ }^{\circ} \mathrm{C}\right)$ is lower than that of the star D- 
sorbitol-PCL synthesised by eROP in $\operatorname{scCO}_{2}\left(N_{\text {arms }}\left({ }^{31} \mathrm{P}\right)=3.2, T_{\mathrm{m}}=41{ }^{\circ} \mathrm{C}\right)$, which in turn is lower than the $T_{\mathrm{m}}$ of the hexanediol-PCL synthesised using $\mathrm{Sn}(\mathrm{Oct})_{2}$ in the bulk $\left(N_{\mathrm{arms}}\left({ }^{31} \mathrm{P}\right)=\right.$ $\left.2, T_{\mathrm{m}}=45^{\circ} \mathrm{C}\right)($ Table S3).

Multiple melting peaks have also been reported in the literature for both linear poly $(L$-lactic acid $)^{74}$ and also for star-shaped poly $\left(L\right.$-lactic) acid. ${ }^{75}$ This observation is attributed to the presence of crystalline domains of different size and different perfection.

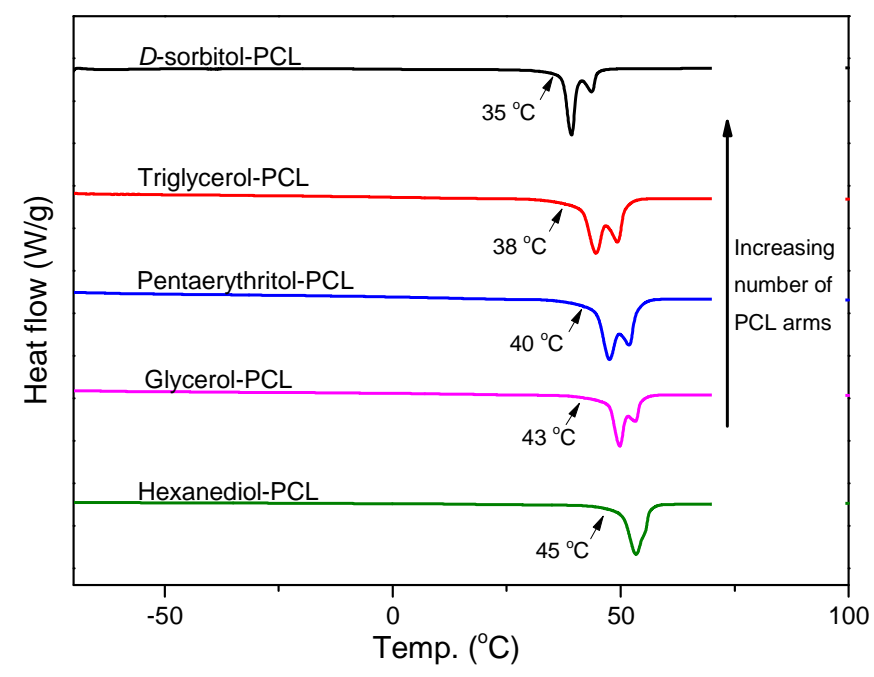

Figure 9. Comparison of DSC thermogram of polyol-PCL. The melting temperatures were obtained from the second heating scan. 


\section{Conclusion}

A sustainable route for star-shaped poly( $\varepsilon$-caprolactone) synthesis was implemented using renewable feedstock in clean solvents $\left(\mathrm{scCO}_{2}\right.$ and bulk). The effect of the catalytic system $\left(\mathrm{Sn}(\mathrm{Oct})_{2}\right.$ and Novozym 435) on the architecture of star polymer was investigated in detail by NMR $\left({ }^{1} \mathrm{H}\right.$ and $\left.{ }^{31} \mathrm{P}\right)$, MALDI-TOF, SEC-MALS and Mark Houwink plot. Depending on the differences in architecture, the star polyol-PCLs show different thermal properties, where the melting temperature and crystallisation temperature decrease with increasing number of arms as evidenced by DSC.

Using $\mathrm{scCO}_{2}$, the star synthesis can be performed at a significantly lower temperature $\left(95^{\circ} \mathrm{C}\right)$ as opposed to bulk synthesis $\left(140^{\circ} \mathrm{C}\right)$ with $\mathrm{Sn}(\mathrm{Oct})_{2}$ catalyst. Besides, a significant reduction of the induction period $(<15 \mathrm{~h})$ was observed in $\mathrm{scCO}_{2}$ in comparison to the bulk reaction (75 h) performed at the same temperature $\left(95^{\circ} \mathrm{C}\right)$ while maintaining a regular star architecture. Well-defined, star D-sorbitol-PCL with 5 arms, narrow dispersities $(\fallingdotseq=1.03-1.12)$ and an excellent agreement between targeted and experimental molecular weight $\left(M_{\mathrm{n}}^{\text {targ }}=6000 \mathrm{~g}\right.$ $\mathrm{mol}^{-1}$ and $M_{\mathrm{n}}{ }^{\text {SEC-MALS }}=5500-6100 \mathrm{~g} \mathrm{~mol}^{-1}$ ) were achieved in both the bulk and in $\mathrm{scCO}_{2}$. The synthesis of star D-sorbitol-PCL by enzyme whether in the bulk $\left(91 \%\right.$ in $7 \mathrm{~h}$ at $\left.60{ }^{\circ} \mathrm{C}\right)$ or in $\mathrm{scCO}_{2}\left(96 \%\right.$ in $7 \mathrm{~h}$ at $\left.60{ }^{\circ} \mathrm{C}\right)$ is much faster even at significantly lower temperatures compared to the $\mathrm{Sn}(\mathrm{Oct})_{2}$ catalyst in the bulk $\left(97 \%\right.$ in $10.5 \mathrm{~h}$ at $\left.140^{\circ} \mathrm{C}\right)$ and in $\mathrm{scCO}_{2}(96 \%$ in $56 \mathrm{~h}$ at $\left.95^{\circ} \mathrm{C}\right)$.

Novozym 435 with a CaLB loading as low as 0.3 and $1 \mathrm{wt} \%$ was employed in $\mathrm{scCO}_{2}$ which successfully resulted in star architectures of $D$-sorbitol-PCL with lower dispersities and higher molecular weight than in the bulk $\left(\bigoplus=1.23-1.24\right.$ vs. $1.34-1.36$ and $M_{\mathrm{n}}{ }^{\text {SEC-MALS }}=$ $10100-8800 \mathrm{~g} \mathrm{~mol}^{-1}$ vs. $5650-7800 \mathrm{~g} \mathrm{~mol}^{-1}$ ). These data clearly highlight that a combination of $\mathrm{scCO}_{2}$ and Novozym 435 could provide a fully green route to novel star 
polymers that completely avoids the use of volatile organic solvents and metal catalysts. The star architectures from eROP show a reduced number of arms ( $N_{\text {arms }}$ close to 3$)$ but longer individual arms when compared to those obtained from traditional catalyst $\operatorname{Sn}(\mathrm{Oct})_{2}$. Moreover, the eROP route leaves residual unreacted hydroxy groups on the core, something that cannot be achieved by a metal catalyst.

Acknowledgement: The authors would like to acknowledge SINCHEM Joint Doctorate Programme-Erasmus Mundus Action (framework agreement $\mathrm{N}^{\circ} 2013-0037$ ) for funding. We are also indebted to our excellent technical staff ( $\mathrm{Mr} \mathrm{M}$. Dellar and $\mathrm{Mr} \mathrm{R}$. Wilson) for their design and support of our high-pressure apparatus. We also thank Croda plc for their input to the project. 


\section{References}

1 J. A. Galbis, M. D. G. García-Martín, M. V. de Paz and E. Galbis, Chem. Rev., 2016, 116, 1600-1636.

2 J. M. Ren, T. G. McKenzie, Q. Fu, E. H. H. Wong, J. Xu, Z. An, S. Shanmugam, T. P. Davis, C. Boyer and G. G. Qiao, Chem. Rev., 2016, 116, 6743-6836.

3 W. Wu, W. Wang and J. Li, Prog. Polym. Sci., 2014, 46, 55-85.

4 N. H. Aloorkar, A. S. Kulkarni, R. A. Patil and D. J. Ingale, Int. J. Pharm. Sci. Nanotechnol., 2012, 5, 1675-1684.

5 D. J. A. Cameron and M. P. Shaver, Chem. Soc. Rev., 2011, 40, 1761-1776.

6 T. Higashihara, M. Hayashi and A. Hirao, Prog. Polym. Sci., 2011, 36, 323-375.

7 L. J. Fetters, A. D. Kiss, D. S. Pearson, G. F. Quack and F. J. Vitus, Macromolecules, 1993, 26, 647-654.

8 J. R. Schaefgen and P. J. Flory, J. Am. Chem. Soc., 1948, 70, 2709-2718.

9 M. A. Woodruff and D. W. Hutmacher, Prog. Polym. Sci., 2010, 35, 1217-1256.

10 M. Labet and W. Thielemans, Chem. Soc. Rev., 2009, 38, 3484-3504.

11 R. M. Mohamed and K. Yusoh, Adv. Mater. Res., 2015, 1134, 249-255.

12 T. Buntara, S. Noel, P. H. Phua, I. Melián-Cabrera, J. G. de Vries and H. J. Heeres, Angew. Chemie Int. Ed., 2011, 50, 7083-7087.

13 A. Caretto, M. Noè, M. Selva and A. Perosa, ACS Sustain. Chem. Eng., 2014, 2, 21312141.

14 S. M. Thomas, R. DiCosimo and V. Nagarajan, Trends Biotechnol., 2002, 20, 238242.

15 M. Irfan, J. Oh, S. G. Musharraf, M. R. Shah, S. Ahmed and M. I. Malik, RSC Adv., 2016, 6, 98117-98127. 
16 M. Sobczak, E. Witkowska, E. Olędzka and W. Kolodziejski, Molecules, 2008, 13, 96-106.

17 S. Huang, J. Xiao, Y. Zhu and J. Qu, Prog. Org. Coatings, 2017, 106, 60-68.

18 C.-M. Dong, K.-Y. Qiu, Z.-W. Gu and X.-D. Feng, Macromolecules, 2001, 34, 46914696.

19 F. Sanda, H. Sanada, Y. Shibasaki and T. Endo, Macromolecules, 2002, 35, 680-683.

20 M. D. Deokar, S. B. Idage, B. B. Idage and S. Sivaram, J. Appl. Polym. Sci., 2016, 133, $1-12$.

21 C. Lu, L. Liu, S. R. Guo, Y. Zhang, Z. Li and J. Gu, Eur. Polym. J., 2007, 43, 18571865.

22 Z. Jia, Y. Zhou and D. Yan, J. Polym. Sci. Part A Polym. Chem., 2005, 43, 6534-6544.

23 C. Marques, R. Tarek, M. Sara and S. K. Brar, Platf. Chem. Biorefinery, 2016, 217227.

24 F. H. Isikgor and C. R. Becer, Polym. Chem., 2015, 6, 4497-4559.

25 D. J. A. Cameron and M. P. Shaver, Chem. Soc. Rev., 2011, 40, 1761-1776.

26 A. R. Goddard, S. Pérez-Nieto, T. M. Passos, B. Quilty, K. Carmichael, D. J. Irvine and S. M. Howdle, Green Chem., 2016, 18, 4772-4786.

27 A.-C. Albertsson and R. K. Srivastava, Adv. Drug Deliv. Rev., 2008, 60, 1077-1093.

28 Y. Yang, Y. Yu, Y. Zhang, C. Liu, W. Shi and Q. Li, Process Biochem., 2011, 46, 1900-1908.

29 J. Uppenberg, M. T. Hansen, S. Patkar and T. A. Jones, Structure, 1994, 2, 293-308.

30 A. Kumar and R. A. Gross, Biomacromolecules, 2000, 1, 133-138.

31 F. Deng and R. A. Gross, Int. J. Biol. Macromol., 1999, 25, 153-9.

32 Y. Poojari and S. J. Clarson, Biocatal. Agric. Biotechnol., 2013, 2, 7-11.

33 S. R. Comim Rosso, E. Bianchin, D. De Oliveira, J. V. Oliveira and S. R. S. Ferreira, 36 
J. Supercrit. Fluids, 2013, 79, 133-141.

34 I. K. Varma, A.-C. Albertsson, R. Rajkhowa and R. K. Srivastava, Prog. Polym. Sci., 2005, 30, 949-981.

35 C. Li, T. Tan, H. Zhang and W. Feng, J. Biol. Chem., 2010, 285, 28434-28441.

36 L. Xue, S. Y. Dai and Z. Li, Macromolecules, 2009, 42, 964-972.

37 S. K. Arumugasamy and Z. Ahmad, Asia-Pacific J. Chem. Eng., 2011, 6, 398-405.

38 R. C. Rodrigues, C. Ortiz, Á. Berenguer-Murcia, R. Torres and R. FernándezLafuente, Chem. Soc. Rev., 2013, 42, 6290-6307.

39 Z. Cabrera, G. Fernandez-Lorente, R. Fernandez-Lafuente, J. M. Palomo and J. M. Guisan, J. Mol. Catal. B Enzym., 2009, 57, 171-176.

40 X. Zhou and L. Hong, Colloid Polym. Sci., 2013, 291, 2155-2162.

41 S. P. Nalawade, F. Picchioni and L. P. B. M. Janssen, Prog. Polym. Sci., 2006, 31, 1943.

42 X. Zhang, S. Heinonen and E. Levänen, RSC Adv., 2014, 4, 61137-61152.

43 H. Kröber and U. Teipel, Chem. Eng. Process. Process Intensif., 2005, 44, 215-219.

44 L. Du, J. Y. Kelly, G. W. Roberts and J. M. DeSimone, J. Supercrit. Fluids, 2009, 47, $447-457$.

45 S. Curia, A. F. Barclay, S. Torron, M. Johansson and S. M. Howdle, Philos. Trans. R. Soc. A Math. Phys. Eng. Sci., 2015, 373, 20150073.

46 R. García-Arrazola, D. A. López-Guerrero, M. Gimeno and E. Bárzana, J. Supercrit. Fluids, 2009, 51, 197-201.

47 R. D. Santos, S. R. Rosso Comim, D. de Oliveira, H. Treichel, M. Di Luccio, S. R. S. Ferreira and J. V. Oliveira, Biocatal. Agric. Biotechnol., 2012, 1, 280-283.

48 I. Tsivintzelis, E. Pavlidou and C. Panayiotou, J. Supercrit. Fluids, 2007, 42, 265-272.

49 B. Grignard, F. Stassin, C. Calberg, R. Jérôme and C. Jérôme, Biomacromolecules, 
2008, 9, 3141-9.

50 K. J. Thurecht, A. Heise, M. Degeus, S. Villarroya, J. Zhou, M. F. Wyatt and S. M. Howdle, Macromolecules, 2006, 39, 7967-7972.

51 F. C. Loeker, C. J. Duxbury, R. Kumar, W. Gao, R. A. Gross and S. M. Howdle, 2004, $2450-2453$.

52 S. Curia and S. M. Howdle, Polym. Chem., 2016, 2130-2142.

53 M. Yılmaz, S. Eğri, N. Yıldız, A. Çalımlı and E. Pişkin, Polym. J., 2011, 43, 785-791.

54 C. Jerome and P. Lecomte, Adv. Drug Deliv. Rev., 2008, 60, 1056-1076.

55 J. Li, A. Spina, J. A. Moulijn and M. Makkee, Catal. Sci. Technol., 2013, 3, 1540.

56 P. Taylor, R. F. Storey and A. E. Taylor, J. Macromol. Sci. Part A Pure Appl. Chem., $1998, \mathbf{3 5}, 723-750$.

57 R. F. Storey and J. W. Sherman, Macromolecules, 2002, 35, 1504-1512.

58 D. Bratton, M. Brown and S. M. Howdle, Macromolecules, 2005, 38, 1190-1195.

59 J. L. J. L. Kendall, D. A. Canelas, J. L. J. L. Young and J. M. DeSimone, Chem. Rev., 1999, 99, 543-563.

60 M. Labet and W. Thielemans, Chem. Soc. Rev., 2009, 38, 3484.

61 Y. Mei, A. Kumar and R. A. Gross, Macromolecules, 2002, 35, 5444-5448.

62 A. Córdova, T. Iversen, K. Hult and M. Martinelle, Polymer, 1998, 39, 6519-6524.

63 H. Uyama, K. Inada and S. Kobayashi, Macromol. Biosci., 2001, 1, 40-44.

64 A. S. Kulshrestha, W. Gao and R. A. Gross, Macromolecules, 2005, 38, 3193-3204.

65 S. Kobayashi, Proc. Japan Acad. Ser. B Phys. Biol. Sci., 2010, 86, 338-365.

66 H. Uyama, E. Klegraf, S. Wada and S. Kobayashi, Chem. Lett., 2000, 174, 800-801.

67 M. Weissmuller and W. Burchard, Acta Polym., 1997, 48, 571-578.

68 J. Hu, W. Gao, A. Kulshrestha and R. A. Gross, Macromolecules, 2006, 39, 67896792. 
69 A. Döring, M. Schneider, A. Wycisk and D. Kuckling, International Symposium on GPC/SEC and Related Techniques, 2014, "Branching Analysis of Star Polymers by SEC".

70 B. H. Zimm and W. H. Stockmayer, J. Chem. Phys., 1949, 17, 1301-1314.

71 B. H. Zimm and R. W. Kilb, J. Polym. Sci., 1959, 37, 19-42.

72 A. Spyros, D. Argyropoulos and R. Marchessault, Macromolecules, 1997, 30, 327329.

73 H. Ben and A. J. Ragauskas, Energy and Fuels, 2011, 25, 2322-2332.

74 M. Yasuniwa, S. Tsubakihara, Y. Sugimoto and C. Nakafuku, J. Polym. Sci. Part B Polym. Phys., 2004, 42, 25-32.

75 Y. Zhao, Q. Cai, J. Jiang, X. Shuai, J. Bei, C. Chen and F. Xi, Polymer, 2002, 43, $5819-5825$. 